\title{
Property and Activity of Molybdates Dispersed on Silica Obtained from Various Synthetic Procedures
}

\author{
Antonella Gervasini $^{1^{*}}$, Laura Wahba ${ }^{1,2}$, Manuel Dario Finol ${ }^{3}$, Jean-François Lamonier ${ }^{3}$ \\ ${ }^{1}$ Dipartimento di Chimica Fisica ed Elettrochimica (DCFE), Centro Interdipartimentale Materiali e Interfacce Nanostrutturati \\ (CIMaINa), Università degli Studi di Milano, Milano, Italy; ${ }^{2}$ Department of Material Science, INSTM, University of Milano-Bicocca, \\ Milano, Italy; ${ }^{3}$ Unité de Catalyse et Chimie du Solide UCCS UMR CNRS 8181, Université de Lille 1 Sciences and Technologies, \\ Villeneuve d'Ascq, Lille, France. \\ Email: *antonella.gervasini@unimi.it
}

Received January $18^{\text {th }}, 2012$; revised February $19^{\text {th }}, 2012$; accepted March $24^{\text {th }}, 2012$

\begin{abstract}
The synthesis and characterization of several dispersed molybdena catalysts on silica support $\left(\mathrm{MoO}_{3}-\mathrm{SiO}_{2}\right)$ prepared from a variety of precursors $(\mathrm{Mo}(\mathrm{VI})$-acetylacetonate, oxo-peroxo Mo-species, hydrated ammonium heptamolybdate) and preparation methods (deposition of the Mo-phase on finite $\mathrm{SiO}_{2}$ support by aqueous and methanol impregnations, by adsorption, by oxo-peroxo route-like, and by one-step synthesis of $\mathrm{MoO}_{3}-\mathrm{SiO}_{2}$ system with molecular precursors) are presented. The molybdena concentration on silica was comprised in a large interval (1.5 - $14 \mathrm{wt} \%)$ depending on the preparation method which governed the Mo-loading on silica. Convenient comparisons among samples at similar Mo-concentration have been made discussing the morphologic-structural (XRD, XPS, UV-vis-DRS, and $\mathrm{N}_{2}$-adsorption) and physicochemical (TG-DTG, TPR, and n-butylamine-TPD) sample properties. Polymeric octahedral polymolybdate aggregates predominated in the samples prepared by aqueous and methanol impregnations, which were at high Mo-concentration. On the contrary, isolated $\mathrm{Mo}(\mathrm{VI})$ species in distorted $\mathrm{T}_{\mathrm{d}}$ symmetry predominated in the sample prepared by adsorption which was at very low Mo-concentration. The sample acidity was composed of a weak acidy site population, associated with the silica support, and a strong acid site population associated with the Mo-dispersed phase. Oxidation tests of formaldehyde, an oxygen-containing VOC (Volatile Organic Compound), were performed to determine the prevalent redox or acidic function of the Mo-species at the surface of the catalysts.
\end{abstract}

Keywords: Molybdena-Silica Mixed Oxides; Molybdenum Dispersed Phase; Catalyst Preparation; Catalyst Characterization; Catalytic Oxidation; Formaldehyde

\section{Introduction}

Molybdenum containing catalysts are receiving great interest because of their importance both in environmental catalysis, such as combustion of soot, and in many industrial reactions, such as hydrodesulfuration, dehydrogenation of alkanes, partial oxidation of methanol to formaldehyde, and metathesis of olefins, among others [1-3]. The efficiency of these catalysts is strongly related to the amount and, in particular, the dispersion of the Mo-phase $[4,5]$ which in its turn can be very influenced by the preparation method of the sample [6,7]. To improve the activity-selectivity behavior of the Mo-based catalysts in given reactions and the Mo-dispersion, new Mo-precursors and preparation methodologies are expected helping the development of even more performing catalysts.

Conventionally, hydrated ammonium heptamolybdate

${ }^{*}$ Corresponding author. and impregnation are chosen as Mo-precursor and preparation method, respectively. Because of the acidic character of the aqueous molybdate solutions ( $\mathrm{pH}$ value from 5 to 6) often used in the impregnations, the polymolybdate anions can bound to the support surface and can polymerize/depolymerize during calcinations [8-10] causing alteration of molybdenum aggregation. Supported Mo oxide catalysts can be successfully prepared exploiting the reaction of surface $\mathrm{OH}$ groups of the support with various Mo-organometallic compounds (e.g., $\mathrm{Mo}\left(\eta^{3}-\mathrm{C}_{3} \mathrm{H}_{5}\right)_{4}$, $\mathrm{Mo}_{2}\left(\eta^{3}-\mathrm{C}_{3} \mathrm{H}_{5}\right)_{4}, \mathrm{Mo}\left(\mathrm{C}_{4} \mathrm{H}_{7}\right)_{4}$, etc.), by the so called adsorption equilibrium deposition method [11-13]. It is claimed that the surface of such catalysts bears a uniform distribution of defined Mo species, the structure of which can be controlled changing some synthesis parameter. Another successful synthesis proposed to develop highly dispersed Mo supported catalysts is via the so called oxoperoxo route $[14,15]$ running through formation of low nuclearity oxo-peroxo species (e.g., when silica is con- 
cerned as support, $\equiv \mathrm{Si}-\mathrm{O}-\mathrm{Mo}(\mathrm{OH})\left(\mathrm{O}_{2}\right)_{2}$ moieties are formed). The $\eta^{2}$-peroxo ligands are good leaving groups easily decomposed during calcination to give oxo groups (e.g., $\left.(\equiv \mathrm{Si}-\mathrm{O})_{2}-\mathrm{Mo}(\mathrm{O})_{2}\right)$ with regular distribution on the surface. At last, the design of dispersed metal oxides with high surface area is nowadays attempted by one-step synthesis procedures. For these synthetic procedures, molecular precursors of both the support and metal phase and structure directing agents (like ionic or non-ionic surfactants) are used [16]. This strategy may be used for the synthesis of several supports containing metal oxide phases [17] giving rise to materials with good surface properties and catalytic activities.

Despite the literature presents many papers describing new preparation methods for Mo oxide containing catalysts, comprising those above cited, there is a certain lack of unified vision on the surface and bulk properties of these materials deriving from different preparations and different Mo-precursors.

This work reports our results on the synthesis and characterization of several molybdena containing catalysts over silica support $\left(\mathrm{MoO}_{3}-\mathrm{SiO}_{2}\right)$ prepared from a variety of precursors (Mo(VI)-acetylacetonate, Mo-trioxide, hydrated ammonium heptamolybdate) and preparation methods (deposition of the Mo-phase on the finite $\mathrm{SiO}_{2}$ support by aqueous and methanol impregnations, by adsorption, by oxoperoxo route like, and one-step-synthesis of the $\mathrm{MoO}_{3}-\mathrm{SiO}_{2}$ system). A series of analysis of the main surface and bulk properties governing the catalytic properties of the samples have been made. Primarily, the method of preparation controlled the amount of molybdenum uptake from the silica support. We would like to show that it is possible to modulate the amount and surface properties of the dispersed molybdenum phase by a judicious choice of the Mo-precursor and preparation method. This should have important positive aspects in several applied catalytic fields where Mo-based catalysts are much used. The catalytic oxidation tests of formaldehyde, one among the most toxic indoor volatile organic compounds (belonging to Group 1 of the International Agency for Research on Cancer (IARC) classification [18]), have complemented this study. The product distribution observed on the catalyst samples could permit determining the prevalent redox or acidic function of the Mo species at the surface of the catalysts.

\section{Experimental Procedure}

\subsection{Materials}

The utilized molybdenum precursors were tetra hydrated ammonium heptamolybdate $\left(\mathrm{NH}_{4}\right)_{6} \mathrm{Mo}_{7} \mathrm{O}_{24} \cdot 4 \mathrm{H}_{2} \mathrm{O}$ (SigmaAldrich, 99.98\% purity) (AHM), molybdenum acetylacetonate, $\mathrm{MoO}_{2}\left(\mathrm{C}_{5} \mathrm{H}_{7} \mathrm{O}_{2}\right)_{2}$ (Alfa Aesar, $99 \%$ purity), and molybdenum oxide, $\mathrm{MoO}_{3}$ (Sigma-Aldrich, $95 \%$ purity). Tetra-ethoxy-silane (TEOS, $\mathrm{Si}\left(\mathrm{OC}_{2} \mathrm{H}_{5}\right)_{4}$, Fluka, $98 \%$ purity) was used as silica source. Polyoxyethylenepolyoxypropylene block copolymer $\left(\left(\mathrm{C}_{3} \mathrm{H}_{6} \mathrm{O} \cdot \mathrm{C}_{2} \mathrm{H}_{4} \mathrm{O}\right)_{\mathrm{x}}\right.$, Sigma-Aldrich Pluronic F-68) and hexadecyl-trimethylammonium bromide surfactant $\left(\mathrm{CTAB},\left(\mathrm{C}_{16} \mathrm{H}_{33}\right) \mathrm{N}\left(\mathrm{CH}_{3}\right)_{3} \mathrm{Br}\right.$, Sigma-Aldrich, $99 \%$ purity) were used as structure-directing agents.

VICI Metronic permation tube with para-formaldehyde (grade purum, $\geq 95.0 \%$ ) was used for the catalytic tests of catalytic oxidation.

\subsection{Sample Preparation}

The catalysts with general formula $\mathrm{MoO}_{3} / \mathrm{SiO}_{2}$ were prepared by different methods: by deposition of Mo-molecular precursors on a finite silica support or by one-step synthesis with molecular precursors following a sol-gel procedure.

The mesoporous silica (SIM) support was synthesized by a modification of the procedure described by Huh et al. [19] which consists of a condensation method based on sodium hydroxide-catalyzed reaction of TEOS, in the presence of low concentration of CTAB, followed by acid extraction of the as-made-product in a methanol mixture of hydrochloric acid. Details on the preparation and characterization can be found in Ref. [20]. For this study, the final obtained powder was calcined at $550^{\circ} \mathrm{C}$ during $4 \mathrm{~h}$.

The $\mathrm{MoO}_{3}$-containg samples were prepared depositing the Mo-precursors on SIM by 1) aqueous wet impregnation from the AHM inorganic complex ( $\mathrm{MoSi}$ ing); 2) alcohol impregnation from the $\mathrm{MoO}_{2}\left(\mathrm{C}_{5} \mathrm{H}_{7} \mathrm{O}_{2}\right)_{2}$ organic complex (MoSi_org); 3) adsorption-deposition on silica of Mo ions contained in aqueous solution formed from thermal decomposition of AHM (MoSi ads); 4) oxoperoxo route like method from oxo-peroxo Mo species generated from $\mathrm{MO}_{3}$ in $\mathrm{H}_{2} \mathrm{O}_{2}$ solution (MoSi_oxo). Moreover, a $\mathrm{MoO}_{3} / \mathrm{SiO}_{2}$ sample was prepared by onestep synthesis from TEOS and AHM molecular precursors, as silica and Mo oxide sources, respectively, in the presence of F-68 structure-directing agent (MoSi_os). All the five samples were prepared with the appropriate amounts of Mo-precursor and SIM (or TEOS) to obtain nominal amount of $10 \mathrm{wt} \%$ of Mo on silica. All the samples were calcined at $550^{\circ} \mathrm{C}$ for $4 \mathrm{~h}$ to obtain the final powders.

For the MoSi ing preparation, AHM was dissolved with stirring in water and the required amount of SIM was added. After $16 \mathrm{~h}$ at r.t., solution was stirred at $200^{\circ} \mathrm{C}$ until total water evaporation (rate ca. $5 \mathrm{~cm}^{3} / \mathrm{h}$ ). The obtained yellow solid was dried at $120^{\circ} \mathrm{C}$ for $16 \mathrm{~h}$ (pale yellow dried solid) and eventually calcined. Almost analogously, MoSi_org was prepared dissolving $\mathrm{MoO}_{2}\left(\mathrm{C}_{5} \mathrm{H}_{7} \mathrm{O}_{2}\right)_{2}$ with stirring in methanol at $40^{\circ} \mathrm{C}$ until an intense orange 
clear solution was obtained, (the complete dissolution was controlled by UV-vis measurements at $272 \mathrm{~nm}$ ); then the required amount of SIM was added. Solvent evaporation occurred at $80^{\circ} \mathrm{C}$ (evaporation rate ca. 10 $\mathrm{cm}^{3} / \mathrm{h}$ ), the obtained green solid was dried at $120^{\circ} \mathrm{C}$ for $16 \mathrm{~h}$ (intense green dried solid) and calcined. The preparation of MoSi_ads consisted of several steps; the first step was the decomposition of AHM in water at $100^{\circ} \mathrm{C}$ for $48 \mathrm{~h}$. After filtration, the required amount of SIM was introduced into the obtained clear solution containing Mo ions. In the suspension, $\mathrm{NH}_{4} \mathrm{OH}$ was added to obtain basic solution so favoring the metal cation adsorption on the support; the formed pale yellow suspension was stirred for $24 \mathrm{~h}$ at r.t. (adsorption step). The solid was recovered by filtration under vacuum, it was dried at $120^{\circ} \mathrm{C}$ for $16 \mathrm{~h}$ and calcined.

The MoSi_oxo sample was prepared by oxoperoxo route like, with a modification of the early method described in References [14,15,21]. Initially, $\mathrm{MoO}_{3}$ was dissolved in water at $60^{\circ} \mathrm{C}$ obtaining a pale yellow solution, then a $\mathrm{H}_{2} \mathrm{O}_{2}$ solution $(50 \mathrm{wt} \%)$ was added $\left(\mathrm{H}_{2} \mathrm{O}_{2} /\right.$ $\mathrm{MoO}_{3}$ molar ratio of 25). The required amount of SIM was thus introduced and the pale yellow suspension obtained was stirred for $4 \mathrm{~h}$ at r.t. Finally, the solid was recovered by filtration under vacuum, dried at $120^{\circ} \mathrm{C}$ for $16 \mathrm{~h}$ and calcined.

One step-synthesis of the MoSi_os sample was performed adjusting the synthesis procedure described in Ref. [17]. At first, suitable amount of F68 triblock copolymer (TEOS/F68 molar ratio of 2.3) was dissolved with stirring at $30^{\circ} \mathrm{C}$ up to the formation of a complete clear solution, it was quickly added into a solution of AHM under vigorous stirring. After one hour, $\mathrm{HCl}$ solution (TEOS/HCl $2 \mathrm{M}$ ratio of 0.08 ) and then suitable amount of TEOS were added with stirring at $40^{\circ} \mathrm{C}$ for 24 $\mathrm{h}$. The formed gel was then kept at $100^{\circ} \mathrm{C}$ for $48 \mathrm{~h}$ without stirring; during this time, changes of colors were evidenced (from violet to dark blue to pale green). After being cooling to r.t., the solid was recovered by filtration under vacuum, washing with abundant water, drying at $120^{\circ} \mathrm{C}$ for $16 \mathrm{~h}$ (green-yellow dried solid), and eventually calcined.

\subsection{Sample Characterization}

ICP-OES (Inductively Coupled Plasma Optical Emission Spectroscopy) analyses for the determination of the Mo amount were performed by the ACTIVA apparatus from Horiba JOBIN YVON. The powder samples were attacked by lithium tetraborate at $1100^{\circ} \mathrm{C}$, then dissolved with $\mathrm{HCl}$ (20\% in water) and treated with $\mathrm{H}_{2} \mathrm{SO}_{4}$ plus $\mathrm{HNO}_{3}$ plus $\mathrm{HF}$ in becher, heating up to complete evaporation, and finally recovered with $\mathrm{HNO}_{3}$.

Scanning electron micrographs (SEM) were obtained by a JEOL JSM-5500LV coupled with energy dispersive $\mathrm{X}$-ray spectroscopic (EDS) analyzer working at $20 \mathrm{keV}$ to obtain quantitative information on the distribution of $\mathrm{Mo}$ and Si elements. On each sample, area regions of 100 $\mu \mathrm{m}$ were analyzed.

X-ray diffraction (XRD) patterns of the powder samples were carried out by a Philips PW1710 vertical goniometer diffractometer using $\mathrm{Ni}$-filtered $\mathrm{CuK} \alpha$ radiation $(\lambda=1.5406 \AA)$ with a step size of $1^{\circ}(2 \theta)$ and a step time of $1 \mathrm{~s}$. The patterns were collected over the $2 \theta$ range from $3^{\circ}$ to $80^{\circ}$.

Surface area $\left(\mathrm{S}_{\mathrm{BET}}\right)$ and porosity were determined by $\mathrm{N}_{2}$ adsorption/desorption at $-196^{\circ} \mathrm{C}$ by using a Carlo Erba Sorptomatic 1900 instrument. Details can be found in Ref. [22]. All the samples (45 - 60 mesh particles) were thermally activated before the analysis in the glass-cell at $350^{\circ} \mathrm{C}$ for $16 \mathrm{~h}$ under vacuum. Pore size distribution (PSD) was calculated from the desorption branch of the isotherm using the Barrett-Joyner-Halenda (BJH) model equation [23].

A thermogravimetric (TG) analyzer from PerkinElmer (TGA7) equipped with Pt crucible was used for the measurements of the dried and calcined samples. Analyses were performed in air flowing $\left(60 \mathrm{ml} \cdot \mathrm{min}^{-1}\right)$ at constant rate $\left(10^{\circ} \mathrm{C} \cdot \mathrm{min}^{-1}\right)$ of temperature increasing from $25^{\circ} \mathrm{C}$ to $820^{\circ} \mathrm{C}$.

X-ray photoelectron spectroscopy (XPS) analyses were carried out by a Kratos Analytical AXIS ULTRA DLD spectrophotometer, with $\mathrm{AlK}_{\alpha}$ monochromatized exciting radiation $(1486.6 \mathrm{eV})$. Pass energy of $160 \mathrm{eV}$ or $40 \mathrm{eV}$ for the acquisition of the general $(0-1100 \mathrm{eV})$ or high-resolution (C 1s, O 1s, Si 2p, Mo $3 \mathrm{~d}_{5 / 2}$, and Mo $3 \mathrm{~d}_{3 / 2}$ ) spectra was used, respectively. The residual pressure in the analysis chamber was around $10^{-9}$ mbar. All the binding energy (BE) measurements were corrected for charging effects with reference to the $\mathrm{C} 1 \mathrm{~s}$ photopeak of the adventitious carbon $(284.60 \mathrm{eV})$.

Diffuse reflectance spectroscopy (UV-vis-DRS) measurements were performed on fine powders samples (without any treatment of activation) put into a cell with optical quartz walls by a Perkin-Elmer Lambda 35 instrument equipped with an integrating sphere and Spectralon $^{\circledR}$ as reference material. Spectra were measured in absorbance mode in the $1100-190 \mathrm{~nm}$ range.

Temperature programmed reduction (TPR) experiments were performed in a home-modified Micromeritics Pulse Chemisorb 2700 apparatus. Because the catalysts contained different amounts of reducible Mo-phase, the sample mass used varied from 0.1 to $0.5 \mathrm{~g}$ (45 - 60 mesh particle size) to obtain $\mathrm{k}$ and $\mathrm{P}$ values of $80 \mathrm{~s}$ and $10^{\circ} \mathrm{C}$, respectively $[24,25]$. The samples were initially pretreated in $\mathrm{O}_{2} / \mathrm{Ar}(5.27 \% \mathrm{v} / \mathrm{v})$ flowing $\left(45 \mathrm{~cm}^{3} \cdot \mathrm{min}^{-1}\right)$ at $350^{\circ} \mathrm{C}$ for $1 \mathrm{~h}$. After cooling to $25^{\circ} \mathrm{C}$, the $\mathrm{H}_{2} / \mathrm{Ar}(7.96 \%$ $\mathrm{v} / \mathrm{v})$ reducing mixture flowed through the sample (15 
$\mathrm{cm}^{3} \cdot \mathrm{min}^{-1}$ ) whose temperature increased from $25^{\circ} \mathrm{C}$ to $1050^{\circ} \mathrm{C}$ at constant rate of $8^{\circ} \mathrm{C} \cdot \mathrm{min}^{-1}$, maintaining the final temperature for $30 \mathrm{~min}$. The $\mathrm{H}_{2}$ consumption was detected by a thermal conductivity detector (TCD) and the peak areas were calibrated with pure $\mathrm{H}_{2}$ injections (Sapio, Italy; 6.0 purity).

The acid properties of the silica support and Mo-samples were performed by thermodesorption analysis of n-butylamine (n-But) from saturated samples operating in an home-made modified temperature-programmed desorption mass spectroscopy (TPD-MS) instrument from Thermo Fisher Scientific. The amine saturation was performed on thermally activated sample $\left(350^{\circ} \mathrm{C}\right.$ for 16 h), as described in several papers [26,27]. The TPD-MS analyses were carried out in a tubular quartz cell $(32 \mathrm{~cm}$ long and $1 \mathrm{~cm}$ diameter) equipped with a porous septum for putting the sample (ca. $0.1 \mathrm{~g}, 45$ - 60 mesh particle size) under He flowing $\left(30 \mathrm{ml} \cdot \mathrm{min}^{-1}\right)$ monitoring simultaneously several signals: $12,15,18,30,32,44$, and 73 $\mathrm{m} / \mathrm{e}$ as a function of temperature. At first, an isothermal step at $50^{\circ} \mathrm{C}$ was performed to remove the excess of adsorbed amine from the surface until stable signal was obtained. Then, temperature was raised at $10^{\circ} \mathrm{C} \cdot \mathrm{min}^{-1}$ to $650^{\circ} \mathrm{C}$, maintaining the final temperature for $50 \mathrm{~min}$. Before and after the TPD-MS measurement (at 50 and $650^{\circ} \mathrm{C}$, respectively), known amount of n-But ( $\left.c a .3 \mu \mathrm{L}\right)$ was injected into the sample and the integrated areas of the $m / e=73$ peak were averaged to obtain the calibration factor $( \pm 10 \%$ deviation). Assuming a 1:1 stoichiometry for adsorbed n-But on the acid site, the total number of sites could be known and expressed as equivalent of acid site per sample unit mass or unit surface (mequiv $\cdot \mathrm{g}^{-1}$ or mequiv $\cdot \mathrm{m}^{-2}$ ).

\subsection{Catalytic Test of Formaldehyde Oxidation}

The formaldehyde catalytic oxidation was performed in a fixed bed reactor (i.d. $10 \mathrm{~mm}$ ) loaded with $c a .200 \mathrm{mg}$ of catalyst with particle size of $50-150 \mu \mathrm{m}$. The formalde- hyde vapor was generated heating at $100^{\circ} \mathrm{C}$ permeation tubes containing solid paraformaldehyde and mixed with the carrier gas $\left(20 \% \mathrm{O}_{2} / \mathrm{He}\right)$. The reaction mixture contained $300 \mathrm{ppm}$ of $\mathrm{HCOH}$. The total flow rate was 100 $\mathrm{mL} / \mathrm{min}$ and the gas hourly space velocity (GHSV) was $30,000 \mathrm{~mL} /\left(\mathrm{g}_{\text {cat }} \cdot \mathrm{h}\right)$. The effluent gas from the reactor was analyzed in line by MicroGC (Varian 5400) equipped with Cox and 5CB columns connected to TCD.

Because the observed high adsorption ability of formaldehyde on the samples at room temperature, stable formaldehyde signal was waited before collecting the reactivity data. Once obtained the stable signal at $30^{\circ} \mathrm{C}$, the reactor was heated up from $30^{\circ} \mathrm{C}$ to $450^{\circ} \mathrm{C}$ with a heating rate of $1^{\circ} \mathrm{C} \cdot \mathrm{min}^{-1}$.

\section{Results and Discussion}

\subsection{Prepared Samples}

Table 1 lists the prepared $\mathrm{MoO}_{3} / \mathrm{SiO}_{2}$ samples with the quantitative composition, determined by ICP-OES analysis. The two samples prepared by SIM impregnation from the polynuclear, $\left(\mathrm{NH}_{4}\right)_{6} \mathrm{Mo}_{7} \mathrm{O}_{24} \cdot 4 \mathrm{H}_{2} \mathrm{O}$, and mononuclear, $\mathrm{MoO}_{2}\left(\mathrm{C}_{5} \mathrm{H}_{7} \mathrm{O}_{2}\right)_{2}$, Mo-precursors (MoSi ing and MoSi_org, respectively), had an amount of $\mathrm{MoO}_{3}$ as high as $12-14 \mathrm{wt} \%$. On the contrary, the two samples prepared by metal adsorption and oxo-peroxo route like had lowest amount of $\mathrm{MoO}_{3}$ loaded on SIM, 1.2 and $3.8 \mathrm{wt} \%$, respectively. About the same amount of $\mathrm{MoO}_{3}$ was present in MoSi_os (3.7 wt \%). It clearly emerges that the preparation method had determined the amount of Mo oxide that was loaded on the support. As known, impregnation methods permit introducing the desired amount of metal phase over a given support while by employing other methods of deposition, the mutual characteristics of the support and metal precursor besides the conditions of the synthetic procedure govern the amount of metal which can be up taken by the support.

By assuming a uniform presence of Mo oxide on the

Table 1. Composition and textural properties of the support (SIM) and Mo oxide catalysts.

\begin{tabular}{|c|c|c|c|c|c|c|c|c|}
\hline \multirow[t]{2}{*}{ Sample } & \multicolumn{2}{|c|}{ Composition $\left(w t^{0} \%\right)^{a}$} & \multirow[t]{2}{*}{$\mathrm{S}_{\mathrm{BET}}\left(\mathrm{m}^{2} / \mathrm{g}\right)$} & \multirow[t]{2}{*}{$\begin{array}{c}\text { Mo surface density } \\
\left(\mathrm{at}_{\mathrm{Mo}} / \mathrm{nm}^{2}\right)\end{array}$} & \multirow[t]{2}{*}{ P.V. ${ }^{\mathrm{d}}\left(\mathrm{cm}^{3} / \mathrm{g}\right)$} & \multirow[t]{2}{*}{$P S D^{\mathrm{d}}(\mathrm{nm})$} & \multirow[t]{2}{*}{$\begin{array}{c}\text { Surface } \\
\mathrm{Mo} /(\mathrm{Si}+\mathrm{Mo})^{\mathrm{f}}\end{array}$} & \multirow[t]{2}{*}{ Mo surfacing ${ }^{9}$} \\
\hline & $\mathrm{SiO}_{2}$ & $\mathrm{MoO}_{3}$ & & & & & & \\
\hline SIM & 100 & - & 425 & - & 0.37 & 2.6 & & \\
\hline MoSi_ing & 88.0 & 12.0 & 89 & 0.80 & 0.21 & $1.9 ; 3.7$ & 0.0245 & 0.45 \\
\hline MoSi_org & 86.1 & 13.9 & 199 & 0.93 & 0.16 & $2.1 ; 3.4$ & 0.0353 & 0.56 \\
\hline MoSi_ads & 98.8 & 1.2 & 166 & 0.08 & 0.25 & $2.0 ; 3.2$ & 0.0073 & 1.43 \\
\hline MoSi_oxo & 96.2 & 3.8 & 204 & 0.24 & 0.17 & $2.4 ; 3.5$ & 0.0121 & 0.76 \\
\hline MoSi_os & 96.3 & 3.7 & 529 & n.d. ${ }^{(c)}$ & 0.33 & 3.2 & 0.0159 & 1.01 \\
\hline
\end{tabular}

${ }^{\mathrm{a}}$ Determined by ICP-OES analysis; ${ }^{\mathrm{b}}$ Determined from wt\% of Mo and surface area of SIM; ${ }^{\mathrm{c}}$ Not determined because Mo was not deposited on SIM support; ${ }^{\mathrm{d}}$ Pore Volume, determined at $\mathrm{P} / \mathrm{P}_{0}=0.99$; ${ }^{\mathrm{e}}$ Pore Size Distribution, obtained by BJH method; ${ }^{\mathrm{f}}$ Determined by XPS; ${ }^{\mathrm{g}} \mathrm{Ratio}$ between the Mo-concentration determined from XPS and that from ICP-OES (composition) data. 
SIM support surface and known the SIM surface area, it was possible to compute the Mo surface density of each sample (Table 1). A large range of surface density from ca. 0.1 up to $1.3 \mathrm{at}_{\mathrm{Mo}} \cdot \mathrm{nm}^{-2}$ was found, the lowest densities were observed for the MoSi ads and MoSi_oxo samples and the highest ones for the impregnated samples (MoSi_ing and MoSi_org), as expected.

The formation of the dispersed Mo oxide phase on the silica support necessitated of the calcination step which was carried out at $550^{\circ} \mathrm{C}$. This temperature ensured the complete decomposition of the used Mo-precursors leading to the formation of the oxidic phase, as shown by the TGA results obtained comparing the dried vs. calcined samples. Figures 1-3 report the TGA and DTGA curves for the only dried Mo-samples in the $20^{\circ} \mathrm{C}-820^{\circ} \mathrm{C}$ temperature range collected in flowing air. The curves for MoSi_ing and MoSi_org (Figure 1) are similar; they presented a first loss of weight at very low temperature (ca. $50^{\circ} \mathrm{C}-100^{\circ} \mathrm{C}$ ) associated with physically adsorbed water at the surface or at the pore walls. For higher temperatures, both the curves had a marked loss of mass in the temperature range $200^{\circ} \mathrm{C}-300^{\circ} \mathrm{C}$ due to Mo-complexes decomposition. Ammonia, from the AHM pre-

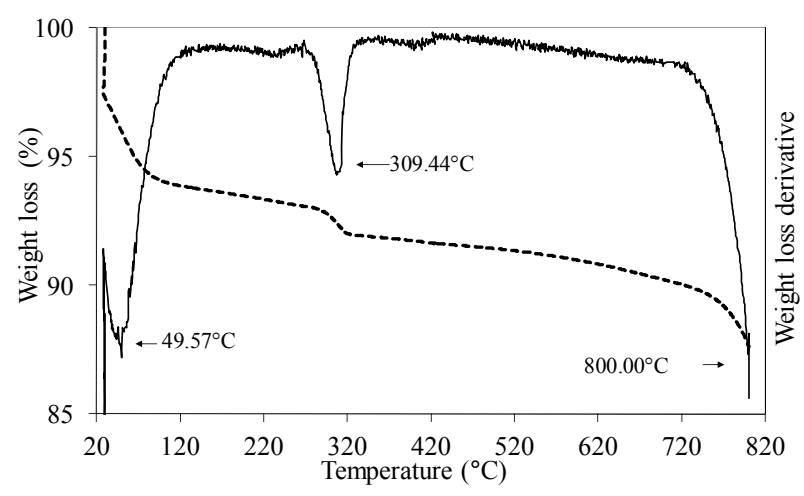

(a)

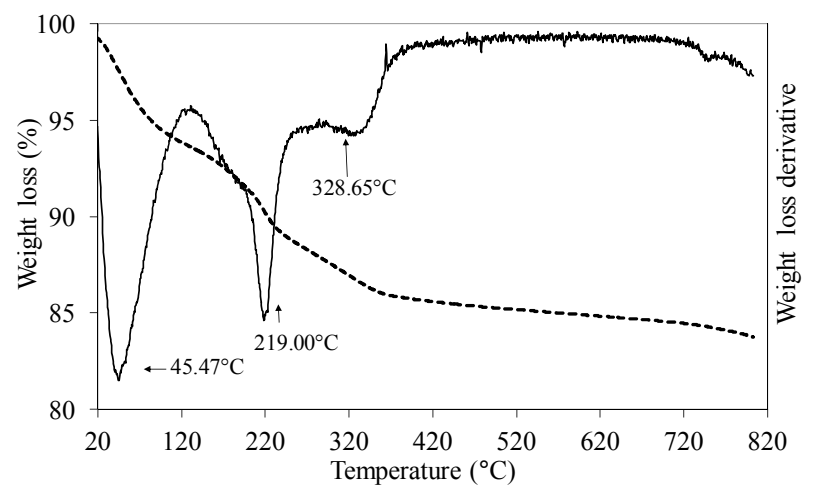

(b)

Figure 1. TGA/DTG profiles in air atmosphere (heating rate of $10^{\circ} \mathrm{C} \mathrm{min}^{-1}$ ) of the dried $\mathrm{MoSi}$ ing (a) and $\mathrm{MoSi}$ _org (b) samples prepared by deposition of $\left(\mathrm{NH}_{4}\right)_{6} \mathrm{Mo}_{7} \mathrm{O}_{24} \cdot 4 \mathrm{H}_{2} \mathrm{O}$ on the SIM support. cursor, completely decomposed at $309^{\circ} \mathrm{C}$ (Figure 1(a)) while the dried MoSi_org had two peaks of mass loss, a pronounced one at $\mathrm{T}_{\max }$ of $219^{\circ} \mathrm{C}$ and a broader one at higher temperature $\left(329^{\circ} \mathrm{C}\right)$. The high temperature zone of the TGA/DTGA curves $\left(>750^{\circ} \mathrm{C}\right)$ gave interesting information; Figure 1(a) showed very pronounced weight of loss at $800^{\circ} \mathrm{C}$ associated with $\mathrm{MoO}_{3}$ sublimation. Figure 1(b) showed the starting of a similar event, in this case the $\mathrm{MoO}_{3}$ sublimation was likely shifted at higher temperature. The difference in sublimation temperature might be due to the use of the polynuclear, $\left(\left(\mathrm{NH}_{4}\right)_{6}\right.$ $\left.\mathrm{Mo}_{7} \mathrm{O}_{24} \cdot 4 \mathrm{H}_{2} \mathrm{O}\right)$, and mononuclear, $\left(\mathrm{MoO}_{2}\left(\mathrm{C}_{5} \mathrm{H}_{7} \mathrm{O}_{2}\right)_{2}\right)$, Mo oxide precursors in the two cases; the first one leading to larger aggregates of Mo oxide on the support surface which can sublimate more easily than the second one, leading to smaller Mo oxide aggregates.

The samples prepared by adsorption and oxo-peroxo route like (MoSi_ads and MoSi_oxo) did not show any clear defined peak of weight loss in the temperature range from $150^{\circ} \mathrm{C}$ to $820^{\circ} \mathrm{C}$, as expected due to the non-use of organic/inorganic complexes to form the Mo oxide dispersed phase (Figure 2).

At last, the TGA-DTGA curves of dried MoSi_os

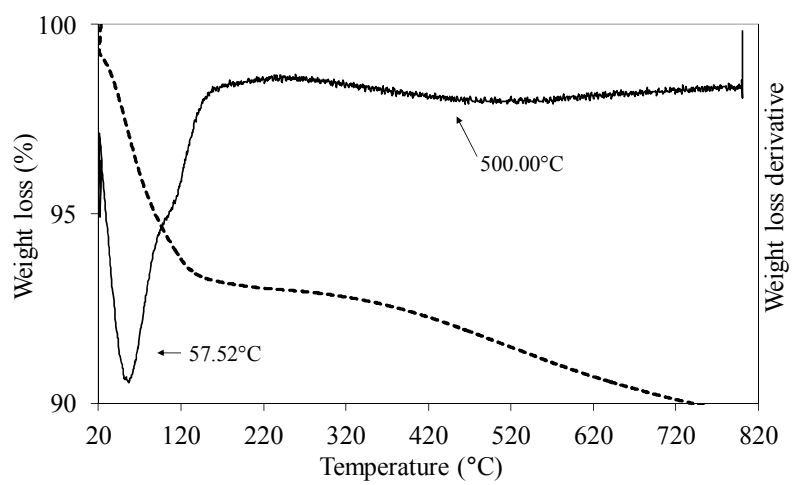

(a)

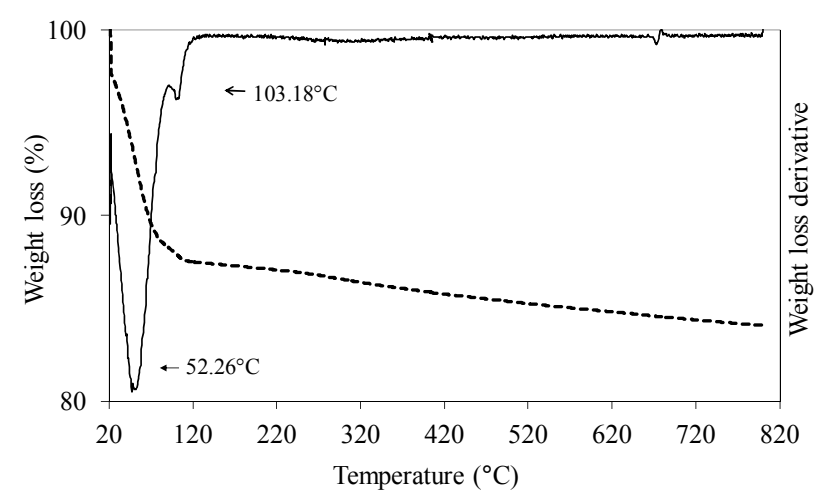

(b)

Figure 2. TGA/DTG profiles in air atmosphere (heating rate of $10^{\circ} \mathrm{C} \mathrm{min}{ }^{-1}$ ) of the dried MoSi_ads (a) and MoSi_oxo (b) samples prepared by adsorption of $\mathrm{Mo}^{6+}$ ions and by addition of $\mathrm{H}_{2} \mathrm{O}_{2} / \mathrm{MoO}_{3}$ solution on the SIM support, respectively. 
showed intense and continuous losses of mass from $50^{\circ} \mathrm{C}$ to $350^{\circ} \mathrm{C}$ range, due to the chemical species used during the sample synthesis (Figure 3).

\subsection{Morphologic-Structural Properties}

All the Mo-sample surfaces were analyzed by SEM-EDS spectrometry to determine the surface composition and the morphologic features. In general, the surface concentration of $\mathrm{MoO}_{3}$, determined by EDS, was lower than that determined from ICP analysis. In particular, a $\mathrm{MoO}_{3}$ concentration of $6.1,10.5,1.45,2.9$, and $1.6 \mathrm{wt} \%$ for $\mathrm{MoSi}$ ing, MoSi_org, MoSi_ads, MoSi_oxo, and $\mathrm{MoSi}_{-}$ os, respectively, was determined.

The low $\mathrm{MoO}_{3}$ surface concentration determined for MoSi ing might be due to the presence of large $\mathrm{MoO}_{3}$ aggregates (3-dimensional particles); in the case of MoSi os, the presence of Mo both on the surface and in the bulk of the sample where it could not be detected by the EDS analysis, can be invoked. For all the other samples, the EDS and ICP measurements were not very different, suggesting that all the Mo loaded on SIM consisted of small Mo oxide aggregates (2-dimensional particles) (see Figure 1 of Supporting Information for a representative SEM image and EDS spectrum).

Concerning the sample BET-surface area values, in general the SIM coverage from Mo oxide phase led to a more or less marked decrease of surface area compared with that of bare SIM; the values are not in any clear relation with the amount of Mo oxide loaded on the support (Table 1). The results suggest that higher surface areas values were obtained when the Mo oxide aggregates could enter into the SIM mesopores while when wider Mo oxide aggregates were formed, they arranged on the external surface of SIM blocking the pore entrance and causing a more important decrease of surface. The pore size distribution (PSD) of SIM presented a unique pore size population (centered at $2.6 \mathrm{~nm}$ of size) while the Mo-samples presented bimodal pore size distributions (Table 1), one of low size (from 1.9 to $2.4 \mathrm{~nm}$ ) and the other of higher size (from 3.2 to $3.7 \mathrm{~nm}$ ). The partial filling of the mesopores of SIM by the Mo oxide aggregates gave rise to the smaller pore size population (PSD $<2.6 \mathrm{~nm}$ ), while the wider Mo oxide aggregates developed a pore size population of larger size (PSD $>3.2 \mathrm{~nm}$ ). The MoSi os sample had very high surface area and porosity $\left(529 \mathrm{~m}^{2} \cdot \mathrm{g}^{-1}\right.$ and $0.33 \mathrm{~cm}^{3} \cdot \mathrm{g}^{-1}$, respectively); a main PSD population around $3.2 \mathrm{~nm}$ of size was observed.

X-ray powder diffraction patterns (XRD) of the Mosamples are compared in Figure 4. In all the patterns, a broad band in the $20^{\circ}-30^{\circ} 2 \theta$ characteristic of unstructured silica appeared. The patterns of the two highest Mo concentrated samples (MoSi_ing and $\mathrm{MoSi}$ org) are similar and reveal the main presence of stable phase or-

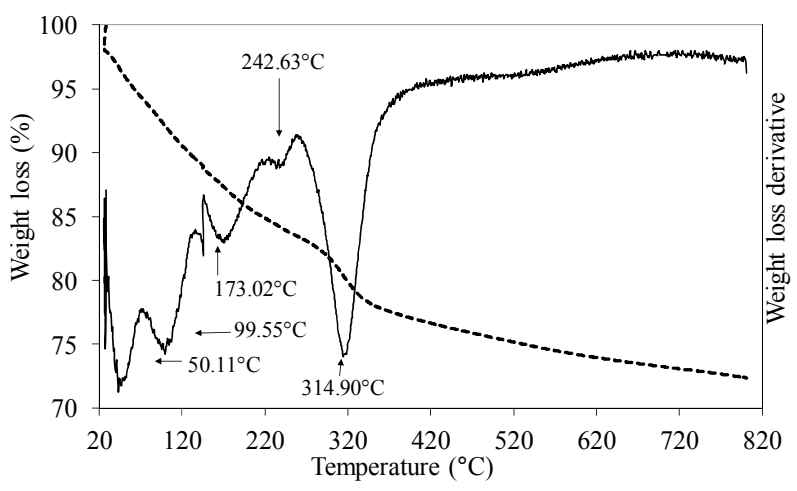

Figure 3. TGA/DTG profiles of the MoSi_os sample prepared by one step synthesis with a sol-gel procedure.

thorhombic $\alpha-\mathrm{MoO}_{3}$ with co-presence of the meta-stable hexagonal $h-\mathrm{MoO}_{3}$, in lower amount. A semi-quantitative evaluation of the cristallite size (by Scherrer law) gave $45-60 \mathrm{~nm}$ for the particle dimension. All the other samples displayed XRD patterns typical of amorphous materials without the possibility to know if the absence of any diffraction peak was due to absence of long-range order of the $\mathrm{MoO}_{3}$ phase or to the too low amount of $\mathrm{MoO}_{3}$ to observe diffraction.

\subsection{XPS Surface Properties}

The identification of the Mo oxidation state by XPS is based on the binding energies of the $\operatorname{Mo}\left(3 \mathrm{~d}_{5 / 2}, 3 \mathrm{~d}_{3 / 2}\right)$ spin-orbit components. It is known that various parameters affect the absolute values of the binding energy of the $\operatorname{Mo}\left(3 \mathrm{~d}_{5 / 2}, 3 \mathrm{~d}_{3 / 2}\right)$ doublet of $\mathrm{Mo}(\mathrm{VI})$-oxo species. Among these, Mo loading, metal-support interaction, and surface oxygen coordination around the Mo centers [2832]. Literature reports special attention on the dependence of the Mo oxide-support interaction on the support nature [31-35]. From these studies, it emerges that the Mo oxide-support interaction strength is reflected by the binding energy value of the Mo $3 d_{5 / 2}$ - Mo $3 d_{3 / 2}$ doublet: the stronger the molybdena-support interaction, the higher the binding energy. In fact, higher binding energy of the Mo $3 d_{5 / 2}-$ Mo $3 d_{3 / 2}$ doublet for the $\mathrm{MoO}_{3} / \mathrm{Al}_{2} \mathrm{O}_{3}$ system in comparison with that of $\mathrm{MoO}_{3} / \mathrm{SiO}_{2}$ is reported. In addition strong metal-support interaction is expected to occur when molybdena is spread on the surface hydroxyl groups of support realizing high Mo-dispersion [36-38].

The collected results (Figures 5-7) show, with some degree of ambiguity, that all the used preparation routines gave to formation of Mo(VI) oxo-species, even if some reduced Mo oxo-species could be co-present. The obtained XPS values corresponded to those reported for supported Mo oxo-species in the highest oxidation state [29-31]. However, the binding energies of Mo $3 d_{5 / 2}$ are shifted at lower values as compared to that of bulk $\mathrm{MoO}_{3}$ 


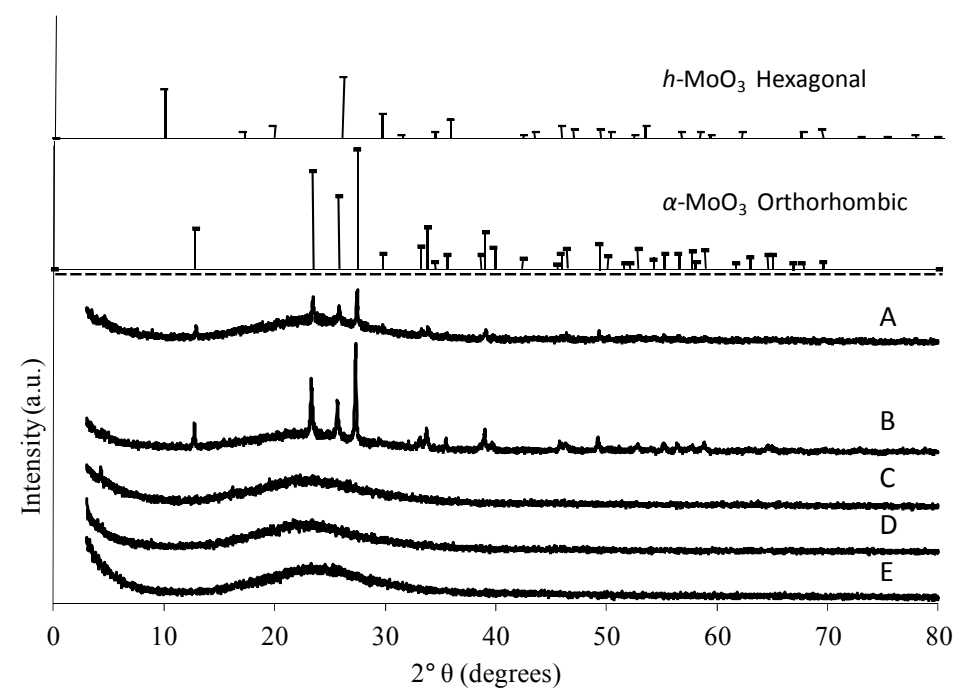

Figure 4. X-ray diffraction patterns of all the Mo-samples: A. MoSi_ing; B. MoSi_org; C. MoSi_ads; D. MoSi_oxo; E. MoSi_os.

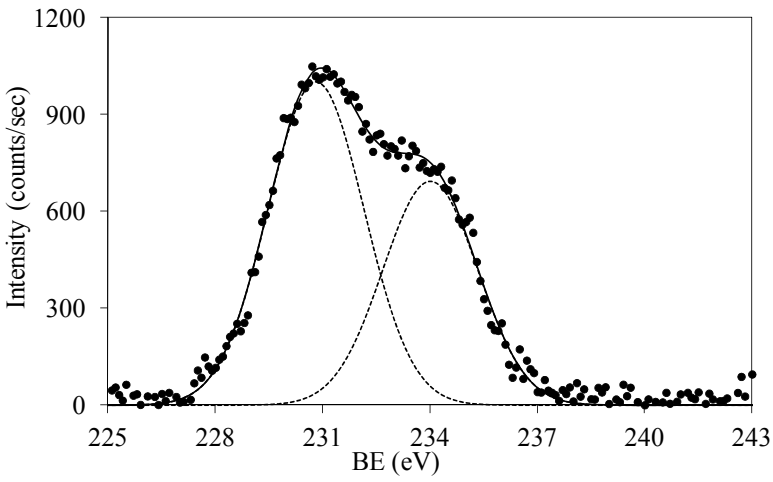

(a)

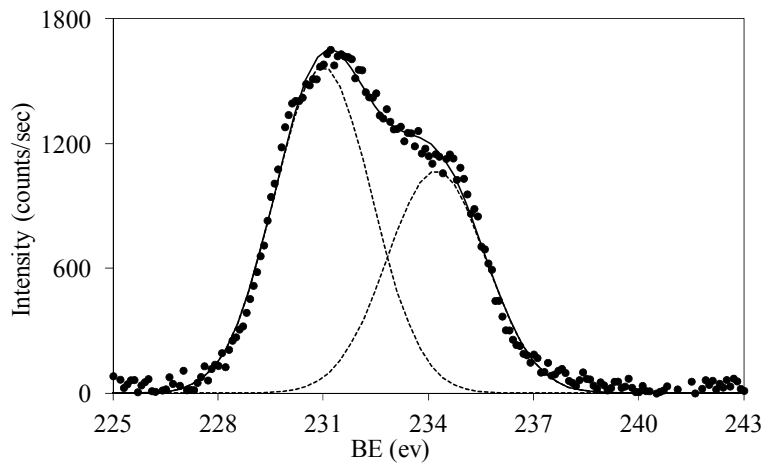

(b)

Figure 5. XPS spectra of the Mo $3 d$ region $\left(M o 3 d_{5 / 2}\right.$ and Mo $3 d_{3 / 2}$ ) for the MoSi_ing (a) and MoSi_org (b) samples with peak decomposition.

(231.7 eV) [39]. This may indicate the surface presence of some reduced Mo species $\left(\mathrm{MoO}_{\mathrm{x}}\right.$ with $\left.\mathrm{x}<3\right)$.

Figures 6 and 7 show that at low molybdena loading (MoSi ads, MoSi oxo, and MoSi os), the doublet is broadened with poor resolved peaks, in comparison with what was observed on MoSi_ing and MoSi_org (Figure

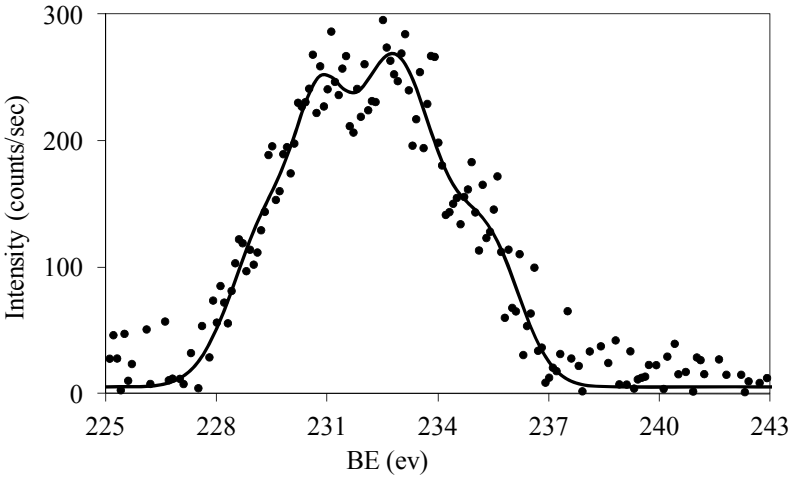

(a)

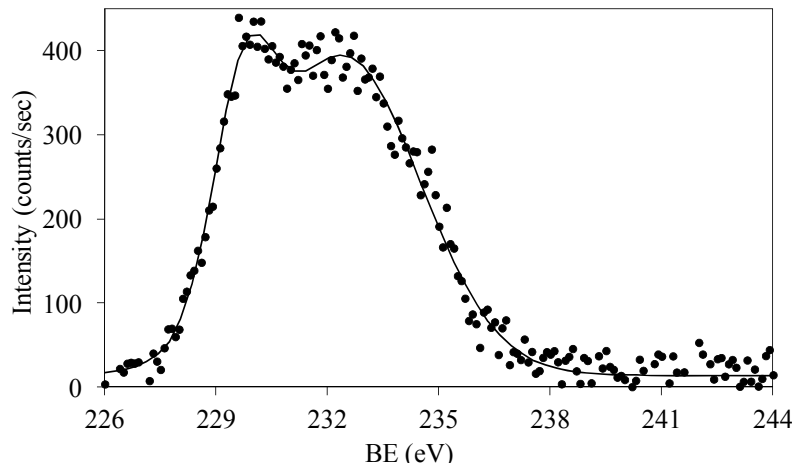

(b)

Figure 6. XPS spectra of the Mo $3 d$ region $\left(M o 3 d_{5 / 2}\right.$ and Mo $3 d_{3 / 2}$ ) for the MoSi_ads (a) and MoSi_oxo (b) samples.

5) for which the width of the peaks has tendency to decrease and the doublet resolution improves.

The broadening of the Mo $3 d_{5 / 2}-$ Mo $3 d_{3 / 2}$ doublet is normally explained either by the presence of several $\mathrm{Mo}(\mathrm{VI})$ oxo-species which differ in the strength of interaction with the support or by the presence of some reduced Mo species [32,40]. MoSi_ing and MoSi_org have 


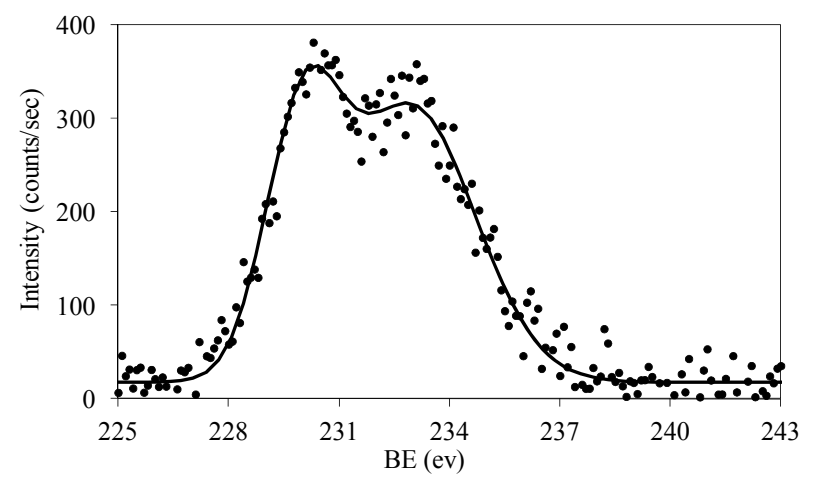

Figure 7. XPS spectra of the Mo $3 d$ region $\left(M o 3 d_{5 / 2}\right.$ and Mo $3 d_{3 / 2}$ ) for the MoSi_os sample.

similar behavior: the $\operatorname{Mo}\left(3 \mathrm{~d}_{3 / 2}, 3 \mathrm{~d}_{5 / 2}\right)$ values are observed at around 234, $231 \mathrm{eV}$, respectively, with intensity ratio,

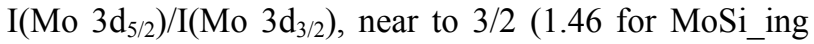
and 1.45 for MoSi_org) and with value of the splitting energy for the Mo $3 d_{5 / 2}-$ Mo $3 d_{3 / 2}$ doublet at $3.2 \mathrm{eV}$, in both the cases.

The fitting of the experimental XPS envelopes of Mosi_oxo and MoSi_os cannot satisfactory be made with only one individual Mo $3 \mathrm{~d}_{5 / 2}$ - Mo $3 \mathrm{~d}_{3 / 2}$ doublet; the low intensity of the photo-peaks prevented a reliable fitting to be computed. The MoSi ads sample showed the more complex situation in which more than two individual $\operatorname{Mo}\left(3 d_{3 / 2}, 3 d_{5 / 2}\right)$ doublets were needed to reproduce the experimental XPS envelopes, suggesting the presence of at least two types of molybdenum species which differ in the strength of interaction with the silica support.

Mo surfacing was calculated for all the samples taking into account the surface Mo-concentration, determined from XPS data, and that obtained from ICP-OES (Table 1). In general, values equal or higher than 0.5 were observed in any case. The lowest Mo surface concentrations were found on MoSi_ing and MoSi_org (0.45 and 0.56, respectively). Within the preparation routine of impregnation, the use of the mononuclear Mo precursors led to better dispersion of the Mo oxide phase that the use of the polynuclear complex $\left(\left(\mathrm{NH}_{4}\right)_{6} \mathrm{Mo}_{7} \mathrm{O}_{24} \cdot 4 \mathrm{H}_{2} \mathrm{O}\right)$. Higher surfacing values were found for MoSi_oxo and MoSi_os ( 0.76 and 1.0 , respectively) which are both at low Moloading and high Mo-dispersion. MoSi_ads has the highest Mo surfacing value (1.43). Considering the experimental error in the evaluation of the very low Mo concentration, we can consider that total Mo-dispersion on silica was obtained in this case.

\subsection{UV-VIS-DRS Electronic Properties}

The electronic spectra of the studied Mo-catalysts are characterized by the absence of any absorption in the visible region according to the $\mathrm{d}^{0}$ configuration of molybdenum, which excludes the occurrence of d-d crystal field transitions.

For $\mathrm{MoO}_{3}$, the electron transfer occurs from the oxygen $2 p$ orbital to the metal $d$ orbital; ligand-metal charge transfer (LMCT) bands are then expected dominating the UV region of the electromagnetic spectrum. They can be used for characterizing local surface structures of Mo oxo species dispersed on the silica surface $[41,42]$. Octahedral $\left(\mathrm{MoO}_{6}^{6-}, O_{h}\right)$ or tetrahedral $\left(\mathrm{MoO}_{4}^{2-}, T_{d}\right)$ coordination for the Mo(VI) species of the samples could be identified starting from an inspection of the UV-DRS bands. Traditionally, absorption bands from 250 to 280 $\mathrm{nm}$ have been assigned to $\operatorname{Mo}\left(T_{d}\right)$ and bands from 300 to $330 \mathrm{~nm}$ to $\operatorname{Mo}\left(O_{h}\right)$ [43-45]. Moreover for oxide-supported $\mathrm{Mo}(\mathrm{VI})$, early authors have attributed the formation and growth of the electronic bands above $300 \mathrm{~nm}$ to a change in local molybdenum symmetry from $T_{d}$ to $O_{h}$ [46]. This is also in agreement with the absorption value of some reference Mo-compounds. with tetrahedrally or octahedrally coordinated molybdenum (230 and 325 $330 \mathrm{~nm}$ for $\mathrm{Na}_{2} \mathrm{MoO}_{4}$ and $\left(\mathrm{NH}_{4}\right)_{6} \mathrm{Mo}_{7} \cdot 4 \mathrm{H}_{2} \mathrm{O}$, respectively) [43] There is a less clear and simple situation concerning the attribution of the ligand charge-transfer transitions of the Mo-O-Mo groups, which can be present in $O_{h}$ polymolybdate when high Mo oxide concentration is concerned. The absorption wavelengths attributed to Mo-OMo structures are reported both at 250 - 295 and 320 $340 \mathrm{~nm}[9,47]$, with significant overlap with the absorptions of $\operatorname{Mo}\left(T_{d}\right)$ and $\operatorname{Mo}\left(O_{h}\right)$ species.

On all the samples, the observed broad electronic bands could be decomposed into two main absorption components with satisfactory fitting (Figures 8-10). Maxima are centered at $200-220 \mathrm{~nm}$ and $290-300 \mathrm{~nm}$ with a small tail at higher wavelength $(400 \mathrm{~nm})$ observed only on MoSi_oxo. The UV-DRS spectra of MoSi_ing and MoSi_org (Figure 8) have similar shape of the bands, similar values of the maxima of the decomposed bands, and similar proportion between the lower and higher wavelength bands. The high and low wavelength bands may be assigned to $\mathrm{MoO}_{6}^{6-}$ species in $O_{h}$ symmetry and $\mathrm{MoO}_{4}^{2-}$ species in $T_{d}$ or distorted $T_{d}$ symmetry, respectively. The absence of electronic bands at wavelength higher than $300 \mathrm{~nm}$ suggested us to rule out the presence of large $\mathrm{MoO}_{3}$ nano-aggregates.

MoSi_ads (Figure 9) presents similar situation of MoSi_ing and MoSi_org; in this case there was more clear presence of the $\mathrm{MoO}_{4}^{2-}$ species in $T_{d}$ or distorted $T_{d}$ symmetry which predominated over the $\mathrm{MoO}_{6}^{6-}$ species. MoSi_oxo presents a different situation with absorptions centered at 223 and $303 \mathrm{~nm}$ and a little absorption at very high wavelength of $402 \mathrm{~nm}$. This indicates a broad distribution of Mo species with well tetrahedrally and octahedrally coordinated Mo oxide species and some amount of $\mathrm{MoO}_{3}$ nano-aggregates.

The shape and position of the UV-DRS bands of 


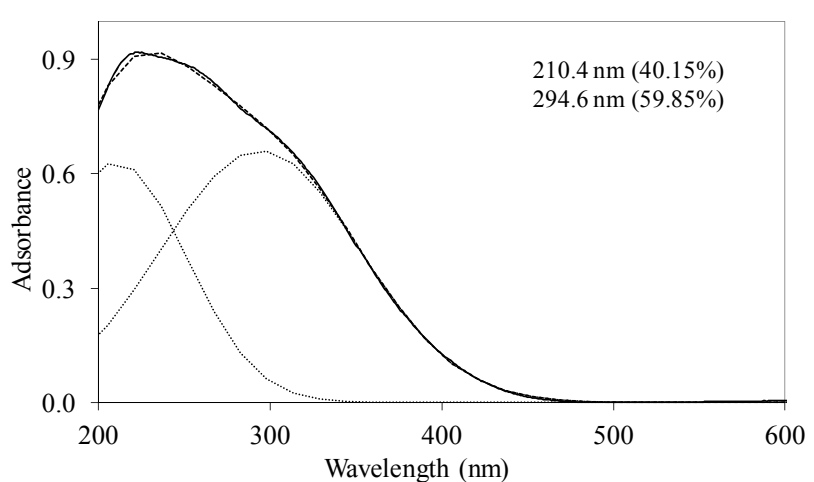

(a)

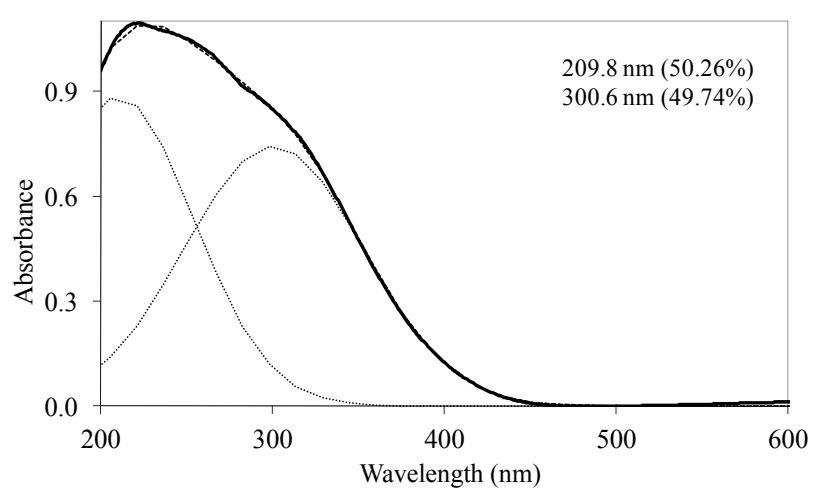

(b)

Figure 8. UV-DRS spectra of the MoSi_ing (a) and MoSi_ org (b) samples with curve peak decomposition. The calculated maximum absorption wavelengths and percentage area of the relevant peaks are indicated.

MoSi_os (Figure 10) are different from of all the others samples. Concerning the peak at lower wavelength, a clear shift towards low wavelength was observed (194 $\mathrm{nm}$ ). The other absorption centered at maximum wavelength of $288 \mathrm{~nm}$ was very prominent and dominated the spectrum; in this case, $O_{h}$ polymolybdate groups might be responsible of the absorption. Mo-reticulation could occur during the synthesis of this sample.

Very recently the literature reports on connected molybdenum oxide centers supported on SBA-15 [48] prepared from molybdenum acetylacetonate in ethanol. In agreement with our findings, these authors found in our same range of Mo-loading (ca. $1 \mathrm{at}_{\mathrm{Mo}} / \mathrm{nm}^{2}$ ) that the molybdenum oxide surface species are composed of both dior oligomeric molybdenum oxide centers and isolated centers, with a mixture of octahedrally Mo-units with connectivity similar to that of $\mathrm{MoO}_{3}$, and tetrahedrallyMo units which are isolated or connected to other $\mathrm{Mo}_{x} \mathrm{O}_{y}$ units. In our case, we generally observed absence of typical UV-DRS bands that could be associated with $3 d$ nanostructured $\mathrm{MoO}_{3}$ aggregates (UV-DRS band with maximum $>300 \mathrm{~nm}$ ) reflecting well dispersion of the supported phase irrespective of the Mo concentration. It

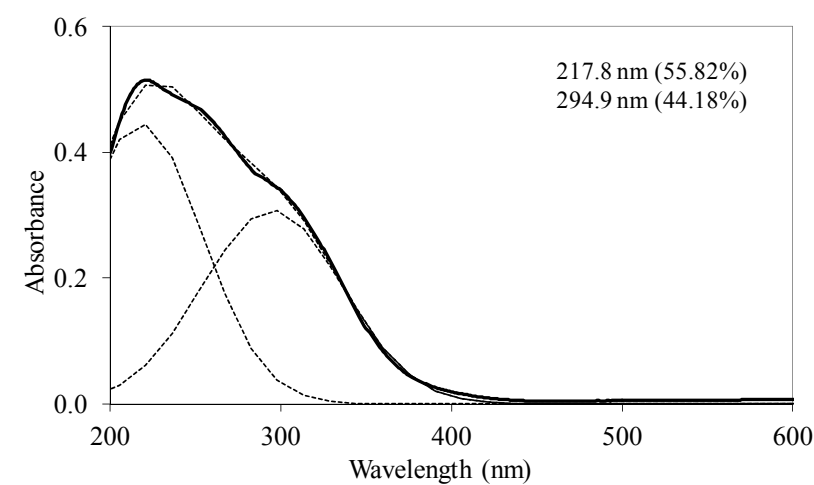

(a)

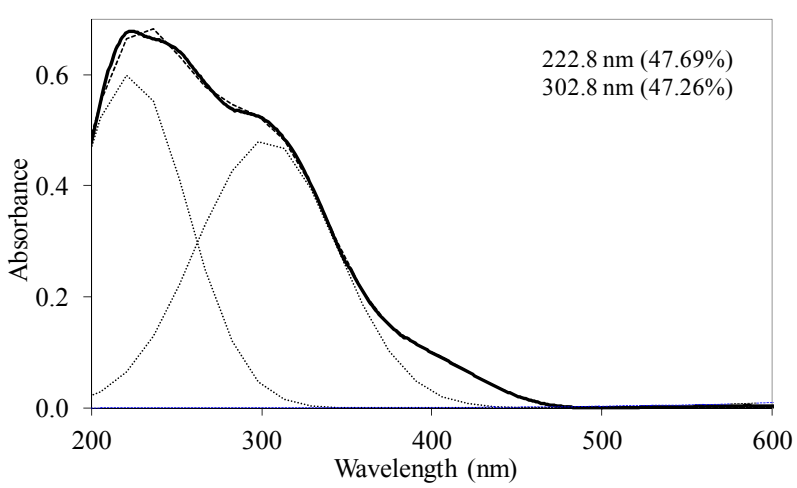

(b)

Figure 9. UV-DRS spectra of the MoSi_ads (a) and MoSi oxo (b) samples with curve peak decomposition. The calculated maximum absorption wavelengths and percentage area of the relevant peaks are indicated.

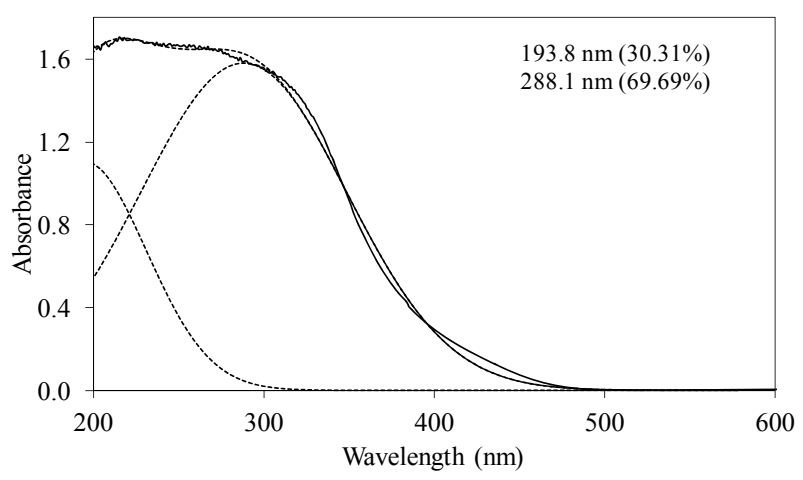

Figure 10. UV-DRS spectra of the MoSi_os sample with curve peak decomposition. The calculated maximum absorption wavelengths and percentage area of the relevant peaks are indicated.

could be guessed that the deposition of Mo oxo centers on silica begins with formation of isolated $\mathrm{Mo}(\mathrm{VI})$ centers in $T_{d}$ or distorted $T_{d}$ symmetry. When the surface Mo concentration increases, symmetry of the metal species changes along with formation of $\mathrm{MoO}_{6}^{6-}$ species in $O_{h}$ symmetry; in fact the broad absorption curve at ca. 300 $\mathrm{nm}$ growths and its maximum shifts from about 290 to 
$305 \mathrm{~nm}$; at last, the high connectivity between Mo-centers gives rise to $O_{h}$ polymolybdate groups. This view is also in agreement with the study of Christodoulakis and Boghosian [5] concerning the formation and growth of the molybdena dispersed phase on zirconia support which was realized by Raman spectroscopy. Direct observation of monomolybdates species and polymeric Mo-oxo units with Mo-O-Mo bridges on zirconia support was reported, the last one predominating at high Mo surface density.

\subsection{Temperature Programmed Reduction ( $\mathrm{H}_{2}$-TPR)}

The $\mathrm{H}_{2}$-TPR profiles of bulk $\mathrm{MoO}_{3}$ activated in the temperature range from $400^{\circ} \mathrm{C}$ to $600^{\circ} \mathrm{C}$ are available in the literature [49-51]. The onset temperature of reduction is around $490^{\circ} \mathrm{C}-530^{\circ} \mathrm{C}$, temperature of peak maxima ( $\mathrm{T}_{\max }$ ) around $740^{\circ} \mathrm{C}-760^{\circ} \mathrm{C}$, and $\mathrm{H}_{2}$ consumption values account the stoichiometric reduction of $\mathrm{MoO}_{3}$ to $\mathrm{Mo}(0)$ $\left(\mathrm{H}_{2} / \mathrm{MoO}_{3}\right.$ molar ratio $\left.=3\right)$. The reduction pattern has been generally rationalized in the light of the stepwise process: $\mathrm{Mo}(\mathrm{VI}) \rightarrow \mathrm{Mo}(\mathrm{IV}) \rightarrow \operatorname{Mo}(0)$. The difficulty in developing a model describing the TPR pattern of the bulk and supported $\mathrm{MoO}_{3}$ systems mostly arises from the occurrence of numerous peaks generated by the various Mo(VI) forms having different reducibility [49]. Concerning the influence of preparation method and support nature on the Mo-speciation, Wachs et al. [52-54] stated that neither the preparation method nor the specific silica used influence the relative distribution of the Mo oxide species, which nature and growth only depend on Moloading.

The obtained TPR profiles reveal very complex shapes with several more or less marked maxima in a large temperature interval without the possibility to clearly distinguish intermediate steps of reduction from Mo(VI) to zerovalent Mo. The complexity of the profiles might be due to the coexistence of various MoSi-oxo species different for coordination type and size and then differently reducible (according with the above discussed UV-DRS results). For all the samples, three main peaks could be individuated corresponding to temperatures $\left(\mathrm{T}_{\max }\right)$ at which maxima reducing rates occurred. The $T_{\max }$ values for all the samples are listed in Table 2: $\mathrm{T}_{\max , 1}$ values are around $500^{\circ} \mathrm{C}, \mathrm{T}_{\max , 2}$ around 700 , and $\mathrm{T}_{\max , 3}$ around $800^{\circ} \mathrm{C}$ or higher. It is expected that [49-55] the more dispersed and isolated $\mathrm{MoO}_{\mathrm{x}}$ species are more difficult to be reduced than the $\mathrm{MoO}_{\mathrm{x}}$ clusters, being the first one in higher contact with the support matrix.

Despite the similar Mo concentration of MoSi_ing and MoSi_org, they showed different TPR profiles (Figure 11); MoSi_org had higher reduction extent at low temperature than MoSi_ing. It can be inferred that more numerous $\mathrm{MoO}_{\mathrm{x}}$ clusters had formed on the MoSi_org sur- face (reduction in the temperature range $500^{\circ} \mathrm{C}-800^{\circ} \mathrm{C}$ ) than on MoSi_ing, while more numerous $\mathrm{MoO}_{\mathrm{x}}$ species in interaction with the support (reduction at temperature higher than $800^{\circ} \mathrm{C}$ ) are present on MoSi ing.

The two samples, MoSi_ads and Mo oxo (Figure 12) have similar TPR profiles, similar amount of $\mathrm{H}_{2}$-consumed, and similar $\mathrm{T}_{\max }$ values (Table 2); only the proportion of the $\mathrm{H}_{2}$-consumed in the low and high temperature interval changes. MoSi_oxo has higher intensity of the TPR peak at low temperature, suggesting the

Table 2. Redox properties of the $\mathrm{MoO}_{3}$ phase determined by $\mathrm{H}_{2}$-TPR measurements.

\begin{tabular}{lccccc}
\hline \multirow{2}{*}{ Sample } & \multirow{2}{\mathrm{H}_{2}\text{consumed}}{$(\mu \mathrm{mol} / \mathrm{g})$} & $\mathrm{H}_{2} / \mathrm{Mo}^{*}$ & \multicolumn{3}{c}{$\mathrm{T}_{\max }\left({ }^{\circ} \mathrm{C}\right)$} \\
\cline { 4 - 6 } & & & $\mathrm{T}_{\max , 1}$ & $\mathrm{~T}_{\max , 2}$ & $\mathrm{~T}_{\max , 3}$ \\
\hline MoSi_ing & 2395 & $2.9(96 \%)$ & 522 & 655 & 855 \\
MoSi_org & 2346 & $2.4(81 \%)$ & 538 & 749 & 817 \\
MoSi_ads & 157 & $1.8(62 \%)$ & 548 & 798 & 979 \\
MoSi_oxo & 512 & $2.0(66 \%)$ & 558 & 767 & 970 \\
MoSi_os & 593 & $2.3(77 \%)$ & 557 & - & $891-932$ \\
\hline
\end{tabular}

${ }^{*} \mathrm{H}_{2}$ /Mo ratio $=3$ for the from the $\mathrm{MoO}_{3}$ to $\mathrm{Mo}(0)$ reduction.

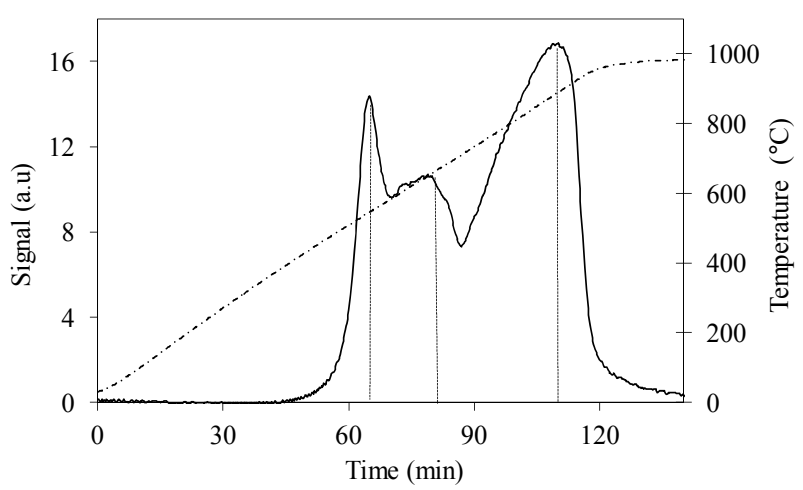

(a)

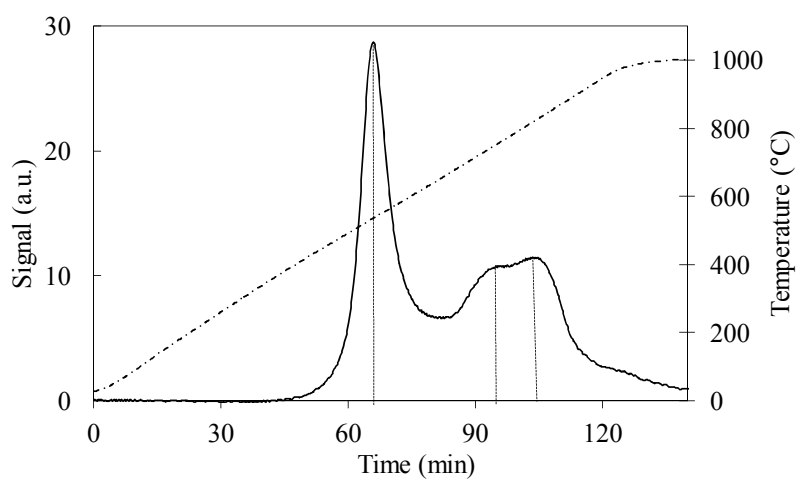

(b)

Figure 11. $\mathrm{H}_{2}$-TPR profiles of the MoSi_ing (a) and MoSi org (b) samples collected in the $30^{\circ} \mathrm{C}-1000^{\circ} \mathrm{C}$ temperature range (see right axis) at heating rate of $8^{\circ} \mathrm{C} \cdot \mathrm{min}^{-1}$. 


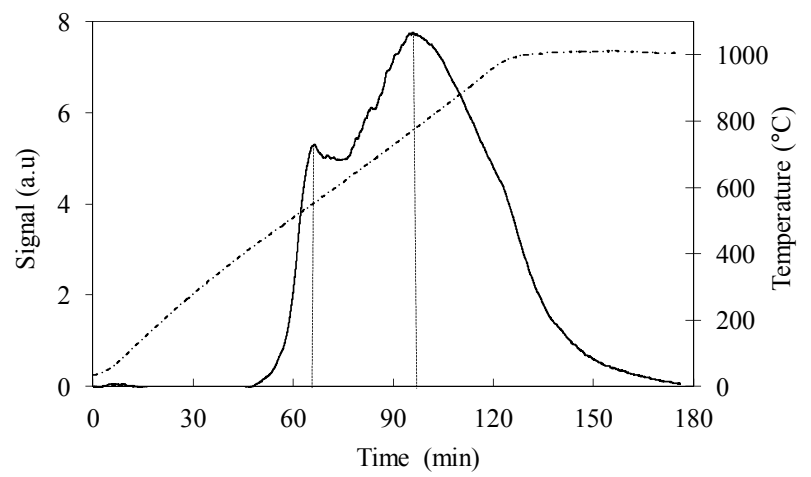

(a)

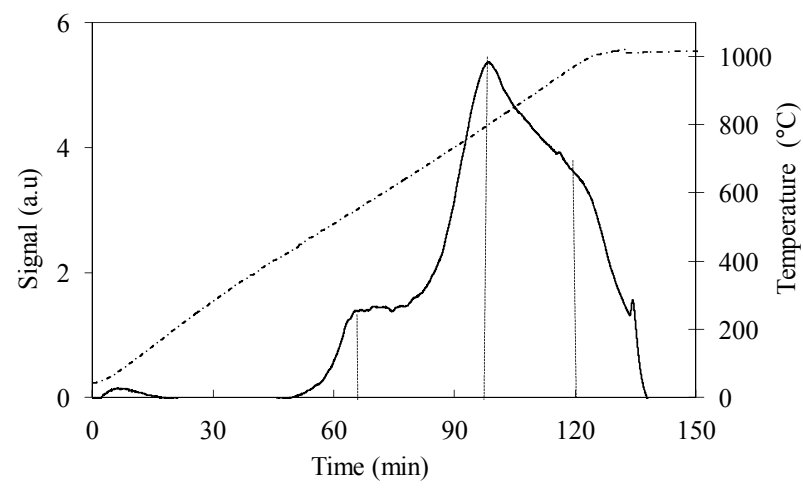

(b)

Figure 12. $\mathrm{H}_{2}$-TPR profiles of the MoSi_ads; MoSi_oxo samples collected in the $30^{\circ} \mathrm{C}-1000^{\circ} \mathrm{C}$ temperature range at heating rate of $8^{\circ} \mathrm{C} \cdot \mathrm{min}^{-1}$.

presence of more easily reducible Mo-species than on MoSi_ads.

The TPR profile of MoSi_os (Figure 13) is very different from all the others. The Mo-reduction starts with a low $\mathrm{H}_{2}$-consumption at $\mathrm{T}_{\max }$ of $557^{\circ} \mathrm{C}$ and then it continues at higher temperatures $\left(891^{\circ} \mathrm{C}-932^{\circ} \mathrm{C}\right)$ with a unique and quite symmetrical peak of reduction of very high intensity. Surely, this sample reveals more homogeneous situation for the Mo-phase in comparison with all the others samples.

\subsection{Acid Properties}

It is generally accepted that the acid properties of the catalytic surfaces determine the activity and selectivity of many reactions, not only in typical acid-base transformations but also in reduction or oxidation reactions [56]. How much acidity can be introduced to a given oxide support by the molybdenum oxide addition is of utmost importance to the catalyst design which has to work in a given reaction. Catalysts containing dispersed Mo centers on oxide supports are known to have high acid properties due to the development of molybdate and polymolybdate species possessing Brönsted and Lewis acid sites [57,58]. The silica surface contains hydroxyl groups which are

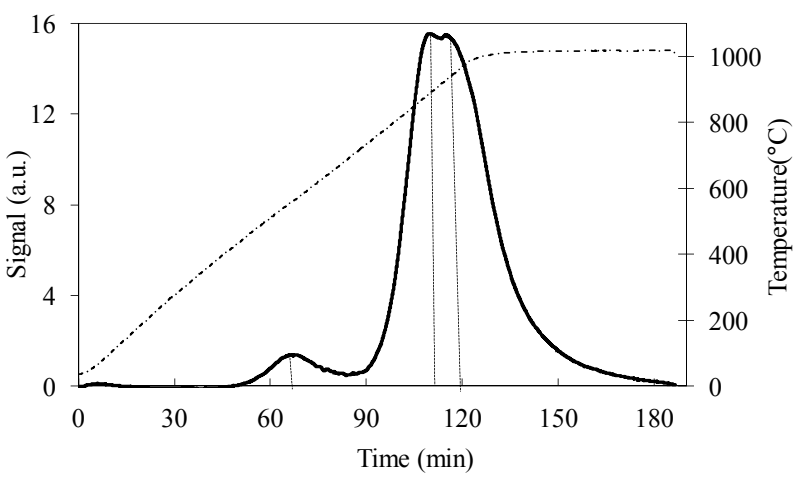

Figure 13. $\mathrm{H}_{2}$-TPR profiles of the MoSi_os sample collected in the $30^{\circ} \mathrm{C}-1000^{\circ} \mathrm{C}$ temperature range (see right axis) at heating rate of $8^{\circ} \mathrm{C} \cdot \mathrm{min}^{-1}$.

weakly acid or neutral, then the deposition of Mo-phase is expected to give rise to a remarkable increase of acidity. Kataoka and Dumesic [57] found both Lewis and Brönsted acidity on high loaded $\mathrm{MoO}_{3} / \mathrm{SiO}_{2}$, whereas they found only Lewis sites in weakly loading systems (1 - $6 \mathrm{wt} \% \mathrm{MoO}_{3}$ ). The Mo loading and the Mo speciation at the sample surface could affect not only the amount of acid sites but also the acid strength and acid distribution.

We chose to study the acid properties of the samples by TPD-MS using n-butylamine as basic probe. This is a conventional approach in the solid acidity studies giving the possibility to determine the amount of acid sites and the acid strength of the sites.

Table 3 reports the obtained results in terms of temperature corresponding to the maximum rate of n-butylamine desorption $\left(\mathrm{T}_{\max }\right)$ and of amount of acid sites per unit mass and per unit surface (meq/g and $\mu \mathrm{eq} / \mathrm{m}^{2}$ ) for the support and Mo-samples. SIM has a homogeneous acid surface (Figure 14) with high amount of acid sites characterized by low acid strength $\left(\mathrm{T}_{\max }=199^{\circ} \mathrm{C}\right)$.

When SIM was covered by high amount of Mo oxide, as for MoSi_ing and MoSi_org (Figure 15), it was found a decrease of the acid site amount because large portion of the acidic support surface was covered, but new stronger acid sites appeared due to the Mo-phase presence. The TPD profiles showed a new peak of desorption at higher temperature than on $\operatorname{SIM}\left(\mathrm{T}_{\max }\right.$ of $218^{\circ} \mathrm{C}$ and $220^{\circ} \mathrm{C}$ for $\mathrm{MoSi}$ ing and MoSi_org, respectively). The desorption peak of n-buylamine associated with the Mosites was about $50 \%$ of the total acidity of the two samples (Table 3).

On MoSi_ads and MoSi_oxo (Figure 16), the acidity presence was not very high, only about $27 \%$ of acid sites had increased acid strength compared with the SIM acid strength.

MoSi_os showed very high amount of acid sites, higher than the support and all the Mo-samples (Figure 17). A peculiar trend for the acid site strength was observed; the low- and high-temperature of n-butylamine desorption 


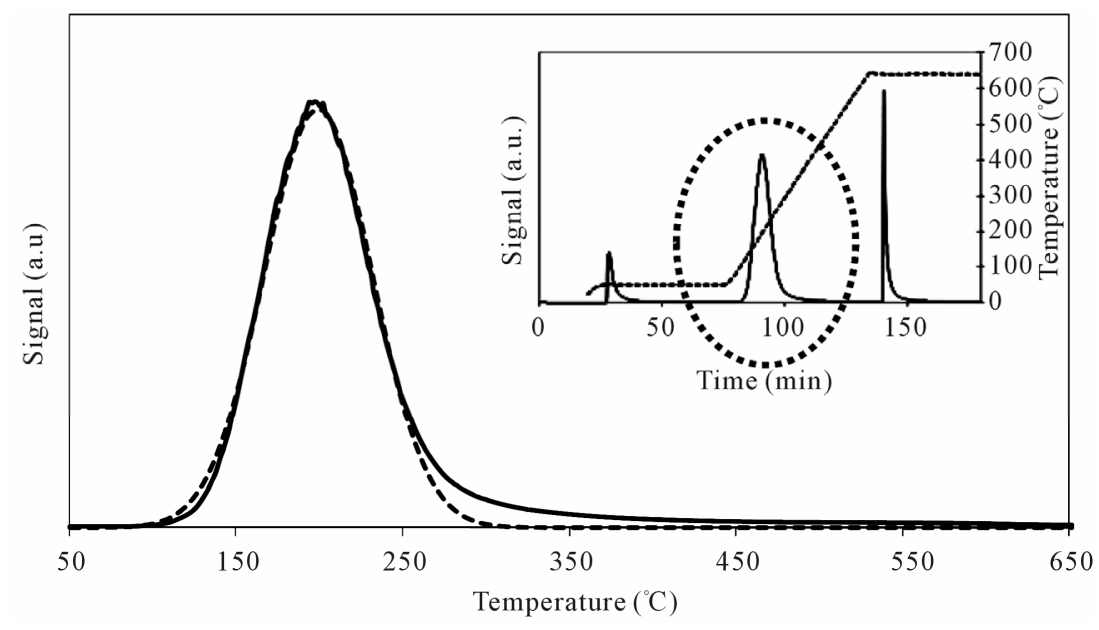

Figure 14. N-butylamine TPD-MS spectra (heating rate, $10^{\circ} \mathrm{C} \cdot \mathrm{min}^{-1} ; 73 \mathrm{~m} / \mathrm{e}$ signal is reported) of the SIM support. Inset reports the development of the whole experiment; before and after n-butylamine TPD, calibration was performed by injecting known amount of butylamine.

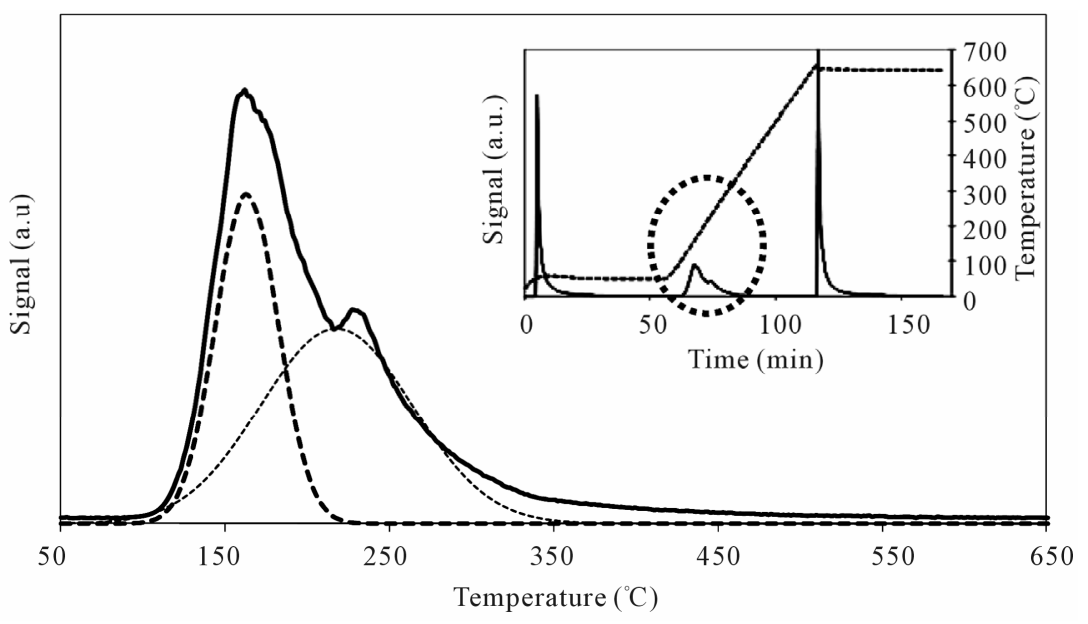

(a)

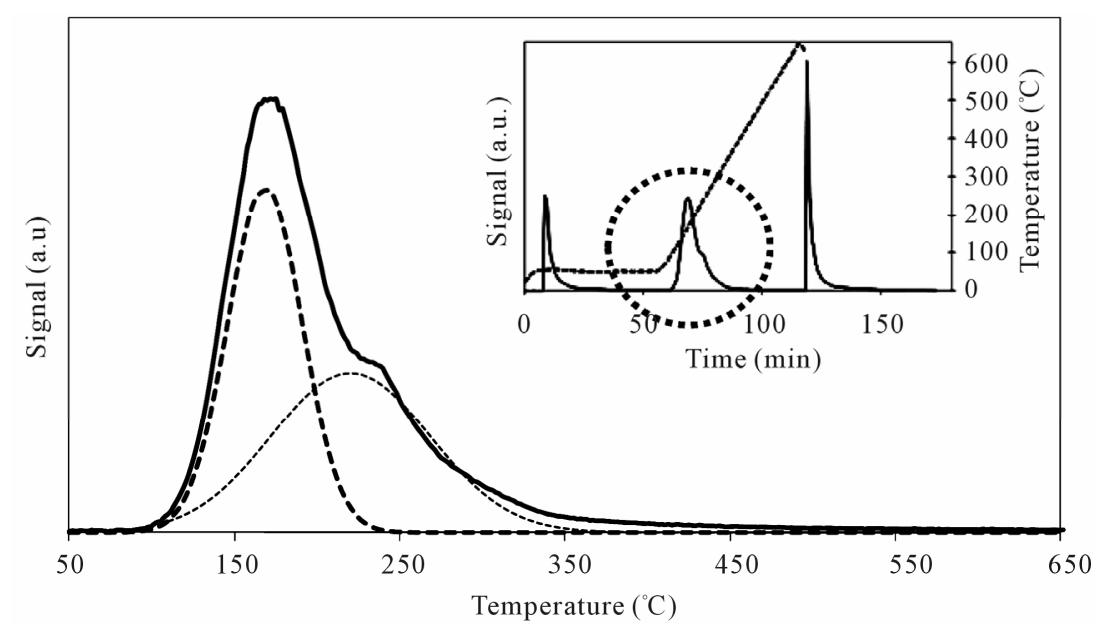

(b)

Figure 15. N-butylamine TPD-MS spectra (heating rate, $10^{\circ} \mathrm{C} \cdot \mathrm{min}^{-1} ; 73 \mathrm{~m} / \mathrm{e}$ signal is reported) of the MoSi_ing (a) and $\mathrm{MoSi}$ org (b) samples. Inset reports the development of the whole experiment; before and after n-butylamine TPD, calibration was performed by injecting known amount of butylamine. 


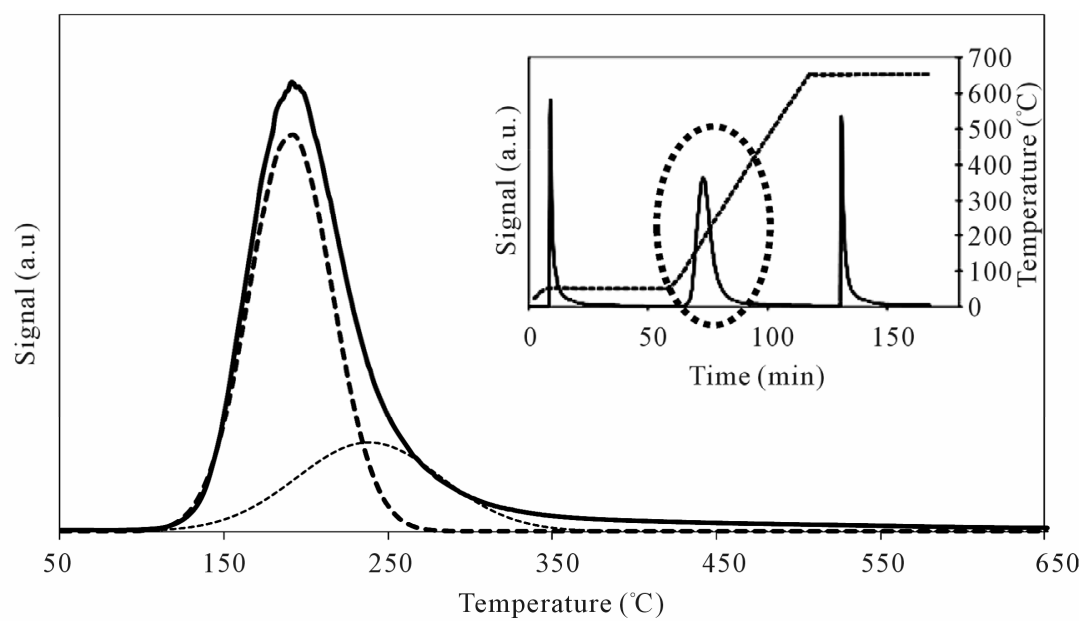

(a)

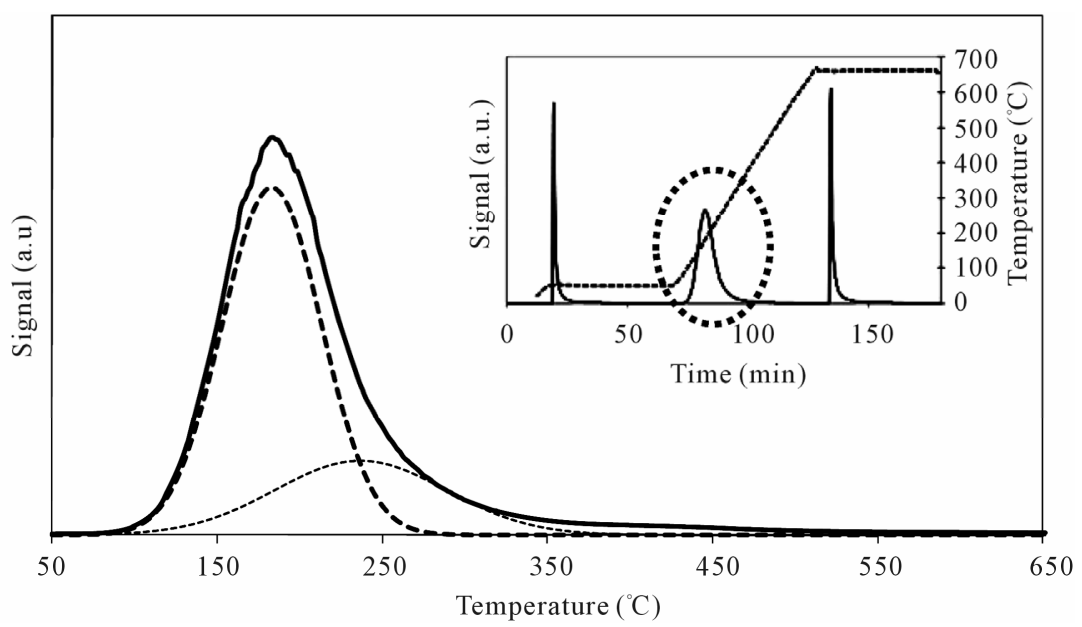

(b)

Figure 16. N-butylamine TPD-MS spectra (heating rate, $10^{\circ} \mathrm{C} \cdot \mathrm{min}^{-1} ; 73 \mathrm{~m} / e$ signal is reported) of the MoSi_ads (a) and MoSi oxo (b) samples. Inset reports the development of the whole experiment; before and after n-butylamine TPD, calibration was performed by injecting known amount of butylamine.

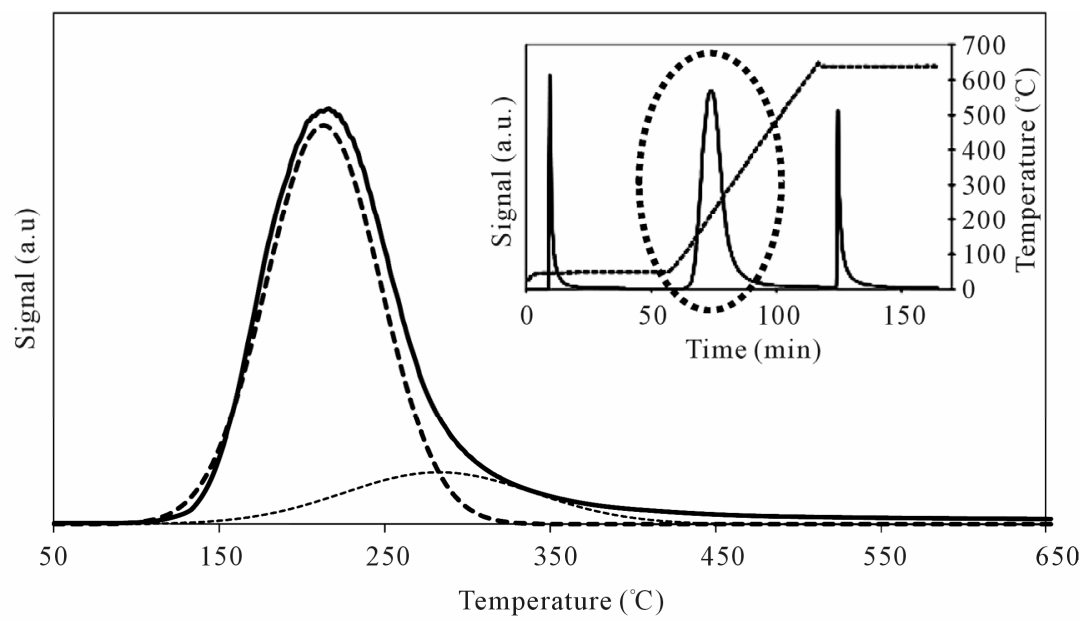

Figure 17. N-butylamine TPD-MS spectra (heating rate, $10^{\circ} \mathrm{C} \cdot \mathrm{min}^{-1} ; 73 \mathrm{~m} / \mathrm{e}$ signal is reported) of the MoSi_os sample. Inset reports the development of the whole experiment; before and after n-butylamine TPD, calibration was performed by injecting known amount of butylamine. 
Table 3. Acidity properties of the samples determined by TPD-MS of n-butylamine desorption*"

\begin{tabular}{ccccc}
\hline \multirow{2}{*}{ Sample } & $\mathrm{T}_{\max 1}\left({ }^{\circ} \mathrm{C}\right)$ & $\mathrm{T}_{\max 2}\left({ }^{\circ} \mathrm{C}\right)$ & \multicolumn{2}{c}{ Acid sites } \\
\cline { 4 - 5 } & & & (mequiv/g) & $\left(\mu \mathrm{equiv} / \mathrm{m}^{2}\right)$ \\
\hline SIM & $199(100 \%)$ & - & 0.737 & 1.74 \\
MoSi_ing & $164(41 \%)$ & $218(59 \%)$ & 0.146 & 1.65 \\
MoSi_org & $169(51 \%)$ & $220(49 \%)$ & 0.161 & 0.81 \\
MoSi_ads & $191(72 \%)$ & $238(28 \%)$ & 0.351 & 2.11 \\
MoSi_oxo & $183(73 \%)$ & $237(27 \%)$ & 0.581 & 2.85 \\
MoSi_os & $213(82 \%)$ & $283(18 \%)$ & 1.21 & 2.29 \\
\hline
\end{tabular}

"quantification was given following $m / e=73$.

peaks were in different positions in comparison with those observed on SIM and on all the others Mo-catalysts (Table 3). The low acidity was prevalent $(82 \%)$ and the high acidity was $c a .18 \%$ of the total. This behavior strengthens the above interpretations from spectroscopy results that polymolybdates were formed on the surface of MoSi_os. The polymolybdate species give rise to Brönsted acid sites which differ in acid strength compared with molybdate species formed on the others samples.

\subsection{Catalytic Activity: Formaldehyde Oxidation}

The catalytic oxidation of formaldehyde vapor gave carbon monoxide and carbon dioxide as only reaction products whatever the catalyst used. The obtained results are presented in the Figures 18-21 as molar fraction of the vented compounds (formaldehyde, carbon dioxide, and carbon monoxide) as a function of reaction temperature. Over SIM (Figure 18), the formaldehyde oxidation was possible but only at temperatures higher than $300^{\circ} \mathrm{C}$ with the highest conversion observed of $28 \%$ at $400^{\circ} \mathrm{C}$. This could be due to the moderate surface acidity of the used silica that was able to adsorb high amount of formaldehyde over it and starting from a given temperature it can be oxidized. In agreement, Mao and Vannice [59] found silica to be inactive for the same reaction in the temperature range between $100^{\circ} \mathrm{C}$ and $240^{\circ} \mathrm{C}$. Cheng [60] showed that silica was relatively inactive as total oxidation catalyst at $300^{\circ} \mathrm{C}$ but it was able to oxidize formaldehyde to methanol and methyl formate, as well as $\mathrm{CO}$ and $\mathrm{CO}_{2}$. More recently McCormick et al. [61] found also that the formaldehyde oxidation over silica leads to $\mathrm{CO}_{2}$ and $\mathrm{CO}$ (with low formaldehyde conversion, $<14 \%$ ) in the temperature range $350^{\circ} \mathrm{C}-400^{\circ} \mathrm{C}$, being $\mathrm{CO}_{2}$ the major product $(75 \%)$.

Over all the Mo containing samples, the catalytic behavior above described was observed, too, but MoSi_org. In general, the increase of formaldehyde conversion and variation between the $\mathrm{CO}$ to $\mathrm{CO}_{2}$ ratio were the main differences observed between the sMo-samples and SIM. Over MoSi_ing and $\mathrm{MoSi}$ org in the high-temperature interval $\left(300^{\circ} \mathrm{C}-450^{\circ} \mathrm{C}\right)$, the $\mathrm{CO}$ product almost disappeared (Figure 19 and Table 4). This result can be explained by the oxidation of $\mathrm{CO}$ into $\mathrm{CO}_{2}$ over the molybdenum species which could work under a classical redox cycle [49] (Mo(VI) $\rightarrow \mathrm{Mo}(\mathrm{IV}))$. MoSi_org catalyst presented a singular catalytic behavior since at very low

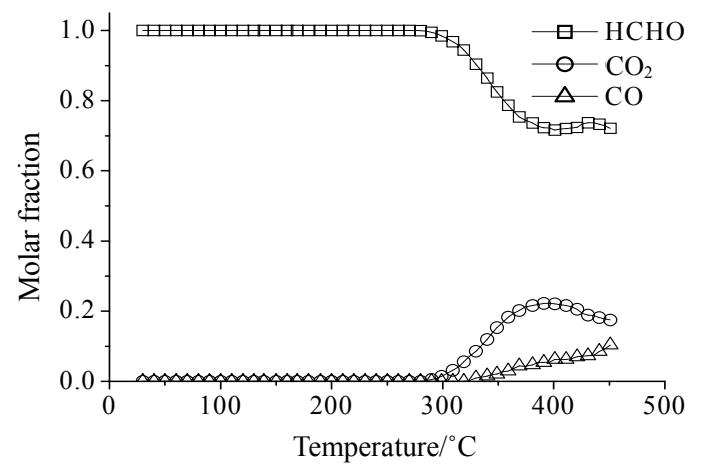

Figure 18. Catalytic test of oxidation of formaldehyde (300 ppm) on the SIM support: molar fraction of the formed products measured as a function of reaction temperature.

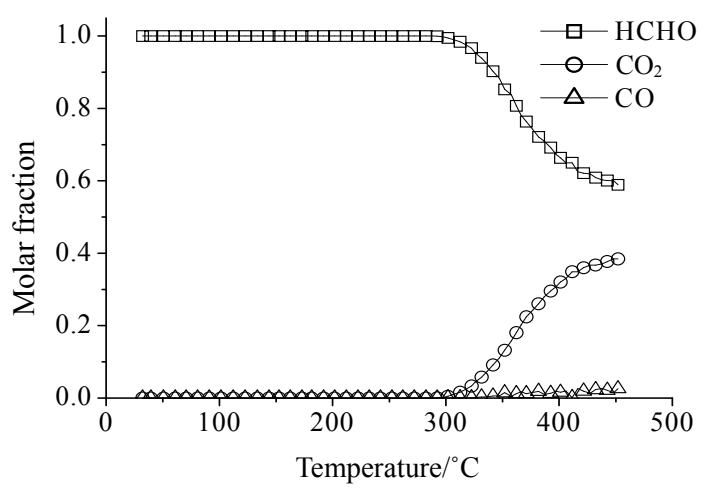

(a)

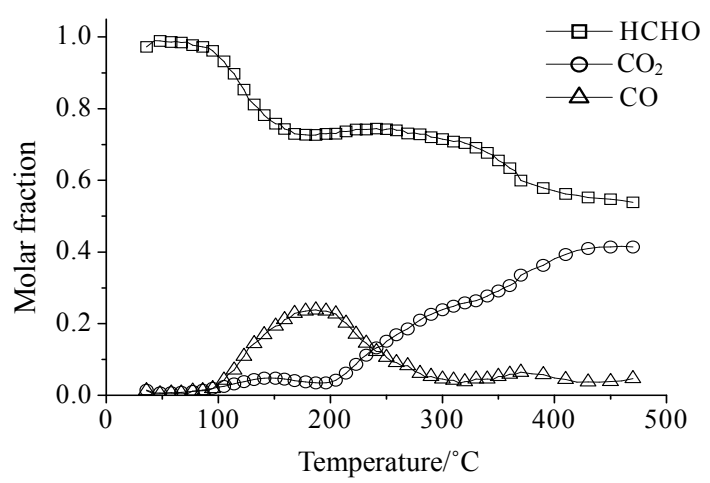

(b)

Figure 19. Catalytic test of oxidation of formaldehyde (300 ppm) on the MoSi_ing (a) and MoSi_org (b) samples: molar fraction of the formed products measured as a function of reaction temperature. 
Table 4. Catalytic results of formaldehyde oxidation*".

\begin{tabular}{|c|c|c|c|c|c|c|c|c|c|}
\hline \multirow{2}{*}{ Sample } & \multirow{2}{*}{ Ton $\left({ }^{\circ} \mathrm{C}\right)$} & \multicolumn{2}{|c|}{$\mathrm{T}_{150}\left({ }^{\circ} \mathrm{C}\right)$} & \multicolumn{2}{|c|}{$\mathrm{T}_{200}\left({ }^{\circ} \mathrm{C}\right)$} & \multicolumn{2}{|c|}{$\mathrm{T}_{300}\left({ }^{\circ} \mathrm{C}\right)$} & \multicolumn{2}{|c|}{$\mathrm{T}_{400}\left({ }^{\circ} \mathrm{C}\right)$} \\
\hline & & $X_{F}(\%)$ & $\mathrm{CO} / \mathrm{CO}_{2}$ & $\mathrm{X}_{\mathrm{F}}(\%)$ & $\mathrm{CO} / \mathrm{CO}_{2}$ & $\mathrm{X}_{\mathrm{F}}(\%)$ & $\mathrm{CO} / \mathrm{CO}_{2}$ & $X_{F}(\%)$ & $\mathrm{CO} / \mathrm{CO}_{2}$ \\
\hline SIM & 285 & - & - & - & - & 1.5 & - & 28.4 & 0.28 \\
\hline MoSi_ing & 295 & - & - & - & - & 0.4 & 0.16 & 33.7 & 0.05 \\
\hline MoSi_org & 71 & 24.2 & 4.02 & 26.8 & 6.24 & 28.5 & 0.19 & 42.9 & 0.13 \\
\hline MoSi_ads & 272 & - & - & - & - & 2.2 & & 32.6 & 0.26 \\
\hline MoSi_oxo & 257 & - & - & - & - & 3.3 & 0.06 & 40.9 & 0.32 \\
\hline MoSi_os & 269 & - & - & - & - & 3.2 & - & 36.9 & 0.71 \\
\hline
\end{tabular}

${ }^{*} \mathrm{X}_{\mathrm{F}}=$ percent conversion of formaldehyde and $\mathrm{CO} / \mathrm{CO}_{2}=$ molar ratio between $\mathrm{CO}$ and $\mathrm{CO}_{2}$ products.

temperature (around $100^{\circ} \mathrm{C}$ ) formaldehyde was converted into CO (Table 4). This catalytic result is hardly to be explained; MoSi_org has higher reduction extent at low temperature than MoSi ing with presence of weaker interaction of the Mo oxo species with the silica support. This behavior can favor the formaldehyde interaction with the Mo centers which can start the oxidation reaction at low temperature.

Concerning the catalytic activity of MoSi_ads, MoSi oxo (Figure 20) and MoSi_os (Figure 21), they all showed similar results. The formaldehyde conversion increased up to $30 \%-40 \%$ at $400^{\circ} \mathrm{C}$ with predominance of $\mathrm{CO}_{2}$, even if $\mathrm{CO}$ was still present among the products at such high temperature (Table 4).

In conclusion, it can be considered that catalyst acidity is suitable to create accumulation of formaldehyde on the sample surface without the ability to oxidize it, while the presence of developed $\mathrm{MoO}_{3}$ structure is beneficial for the oxidation activity which likely passes through a redox mechanism. Based on these consideration, MoSi ing and MoSi_org with large $\mathrm{MoO}_{3}$ aggregates showed the better selectivity to $\mathrm{CO}_{2}$ during reaction at high temperature.

\section{Conclusions}

The possibility to create silica surfaces containing Mo oxo species with high or low Mo content and then associated with more aggregated or dispersed Mo-species if mainly directed by the preparation procedure. The choice of the Mo-precursor is a parameter which lightly affect the final sample properties.

The Mo-speciation distribution obtained on low or high Mo-loading silica samples affect the redox and acid properties of the samples, in particular. The molybdena phase can be in strong interaction or not with the support or the interaction between the metal centers can prevail over the metal-support ones. The acid properties of the Mo-samples were higher when weak metal-support interactions were active; this was observed at medium-high

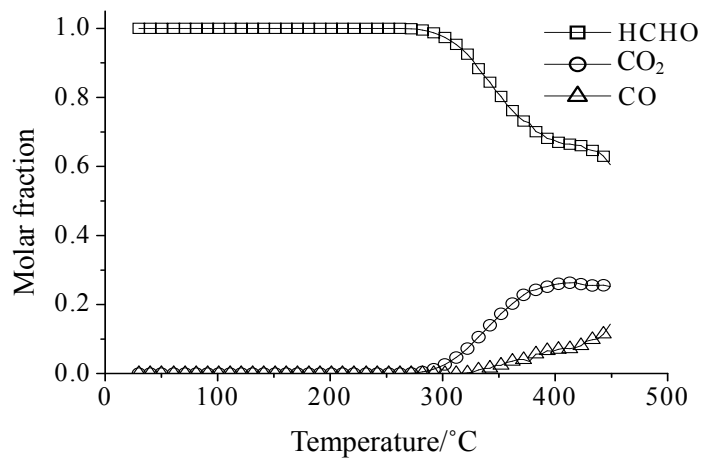

(a)

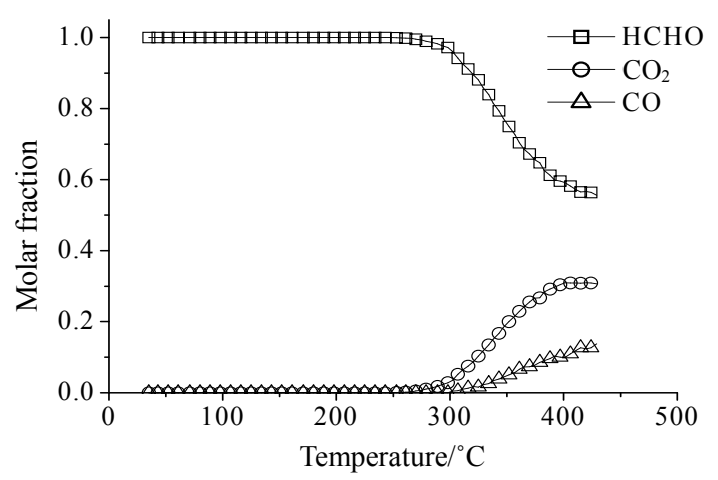

(b)

Figure 20. Catalytic test of oxidation of formaldehyde (300 ppm) on the MoSi_ads (a) and MoSi_oxo (b) samples: molar fraction of the formed products measured as a function of reaction temperature.

Mo-concentration on the surface. The redox properties of the molybdena dispersed phase were enhanced when a critical size structure of $\mathrm{MoO}_{3}$ clusters were formed. A judicious choice of the synthesis parameters of the Mosamples should permit tuning the chemical properties of the samples to obtain surfaces with different chemical properties.

\section{Acknowledgements}

Acknowledgements have to be addressed to Dr. Vladimiro 


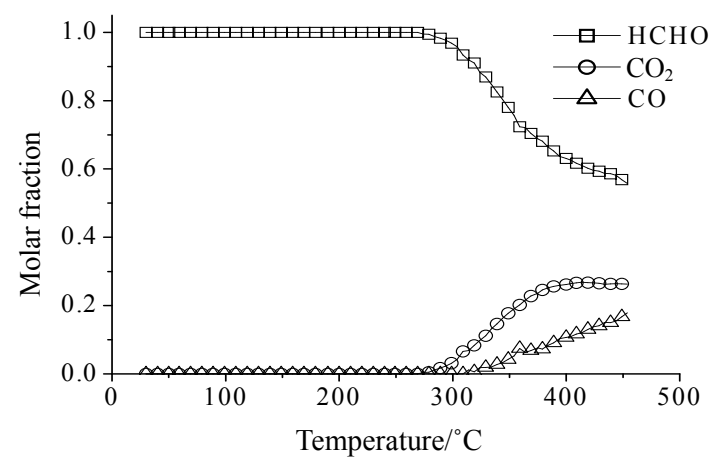

Figure 21. Catalytic test of oxidation of formaldehyde (300 ppm) on the MoSi_os sample: molar fraction of the formed products measured as a function of reaction temperature.

Dal Santo, Consiglio Nazionale delle Ricerche (CNR), Istituto di Scienze e Tecnologie Molecolari, Milano, Italy, for his assistance in several analytic measurements. A Gervasini thanks the University of Lille-1 for the Invited Professor position obtained in 2010, permitting the cooperation between the University of Milan and the University of Lille-1.

\section{REFERENCES}

[1] H. H. Kung, "Transition Metal Oxides: Surface Chemistry and Catalysis," Elsevier, New York, 1989.

[2] G. Centi, "Selective Oxidation by Heterogeneous Catalysis," Kluwer Academic, New York, 2001.

[3] J. G. L. Fierro, "Metal Oxides: Chemistry and Applications," CRC Taylor \& Francis: Boca Raton, 2006.

[4] H. Hair, M. J. Liszka, J. E. Gatt and D. Baertsch, "Effects of Metal Oxide Domain Size, Dispersion, and Interaction in Mixed $\mathrm{WO}_{\mathrm{x}} / \mathrm{MoO}_{\mathrm{x}}$ Catalysts Supported on $\mathrm{Al}_{2} \mathrm{O}_{3}$ for the Partial Oxidation of Ethanol to Acetaldehyde," The Journal of Physical Chemistry C, Vol. 112, No. 5, 2008, pp. 1612-1620. doi:10.1021/jp0763001

[5] A. Christodoulakis and S. Boghosian, "Molecular Structure and Activity of Molybdena Catalysts Supported on Zirconia for Ethane Oxidative Dehydrogenation Studied by Operando Raman Spectroscopy," Journal of Catalysis, Vol. 260, No. 1, 2008, pp. 178-187. doi:10.1016/j.jcat.2008.09.025

[6] N. Al-Yassir and R. Le Van Mao, "Catalysts for the Thermo-Catalytic Cracking (TCC) Process: Interactions between the Yttria in Yttria-Doped Alumina Aerogel and the Mono-Oxide $\mathrm{MoO}_{3}, \mathrm{CeO}_{2}$, and $\mathrm{Bi}-\mathrm{Oxide} \mathrm{MoO}_{3}-\mathrm{CeO}_{2}$ Species," Applied Catalysis A: General, Vol. 332, No, 2, 2007, pp. 273-288. doi:10.1016/j.apcata.2007.08.023

[7] B. Solsona, A. Dejoz, T. García, P. Concepcíon, J. M. Lopez Nieto, M. J. Vázquez and M. T. Navarro, "Molybdenum-Vanadium Supported on Mesoporous Alumina Catalysts for the Oxidative Dehydrogenation of Ethane," Catalysis Today, Vol. 117, No. 1-3, 2006, pp. 228-233. doi:10.1016/j.cattod.2006.05.025

[8] L. Wang and W. K. Hall, "The Preparation and Genesis of Molybdena-Alumina and Related Catalytic Systems,"
Journal of Catalysis, Vol. 77, No. 1, 1982, pp. 232-241. doi:10.1016/0021-9517(82)90163-4

[9] H. Jeziorowski and H. Knoezinger, "Raman and Ultraviolet Spectroscopic Characterization of Molybdena on Alumina Catalysts," The Journal of Physical Chemistry, Vol. 83, No. 9, 1979. pp. 1166-1173. doi: $10.1021 / \mathrm{j} 100472 \mathrm{a} 012$

[10] J. M. Stencel, J. R. Diehl, J. R. D’Este, L. E. Makowsky, L. Rodrigo, K. Marcinkowska, A. Adnot, P. C. Roberge and S. Kaliaguine, "Characterization of Silica-Supported Mo(VI): The Effect of Calcination and Exposure to Water Vapor," The Journal of Physical Chemistry, Vol. 90, No. 20, 1986, pp. 4739-4743. doi:10.1021/j100411a006

[11] D. G. H. Ballard, "Pi and Sigma Transition Metal Carbon Compounds as Catalysts for the Polymerization of Vinyl Monomers and Olefins," Advanced in Catalysis, Vol. 23, 1973, pp. 263-325. doi:10.1016/S0360-0564(08)60303-X

[12] Y. I. Yermakov, "Supported Catalysts Obtained by Interaction of Organometallic Compounds of Transition Elements with Oxide Supports," Catalysis Reviews: Science and Engineering, Vol. 13, No. 1, 1976, pp. 77-120. doi:10.1080/00087647608069935

[13] Y. Iwasawa and M. Yamagishi, "New $\mathrm{SiO}_{2}$-Attached 'Mo-Pair' Catalysts. Preparation, Surface Structure, and Chemical Nature," Journal of Catalysis, Vol. 82, No. 2, 1983, pp. 373-381. doi:10.1016/0021-9517(83)90204-X

[14] J.-Y. Piquemal, J.-M. Manoli, P. Beaunier, A. Ensuque, P. Tougne, A.-P. Legrand and J.-M. Brégeault, "Using Inorganic Silicate Precursor/Molybdenum Peroxo Complexes/Onium Salt Interfaces in Aqueous Acidic Media to Design Mesoporous Silica with High Molybdenum Content and High Dispersion," Microporous and Mesoporous Materials, Vol. 29, No. 3, 1999, pp. 291-304. doi:10.1016/S1387-1811(98)00342-4

[15] P. C. Bakala, E. Briot, L. Salles and J. M. Brégeault, "Comparison of Liquid-Phase Olefin Epoxidation over $\mathrm{MoO}_{\mathrm{x}}$ Inserted within Mesoporous Silica (MCM-41, SBA-15) and Grafted onto Silica," Applied Catalysis A: General, Vol. 300, No. 2, 2006, pp. 91-99. doi:10.1016/j.apcata.2005.09.038

[16] Y. Wan and D. Zhao, "On the Controllable Soft-Templating Approach to Mesoporous Silicates," Chemical Reviews, Vol. 107, No. 7, 2007, pp. 2821-2860. doi:10.1021/cr068020s

[17] A. Bordoloi, A. Vinu and S. B. Halligudi, "One-Step Synthesis of SBA-15. Containing under Tungsten Oxide Nanoclustures: A Chemoselective Catalyst for Oxidation of Sulfides to Sulfoxides at Ambient Conditions," Chemical Communication, Vol. 45, 2007, pp. 4806-4808. doi:10.1039/b709459k

[18] T. Salthammer, S. Mentese and R. Marutzky, "Formaldehyde in the Indoor Environment," Chemical Reviews, Vol. 110, No. 4, 2010, pp. 2536-2572. doi: $10.1021 / \mathrm{cr} 800399 \mathrm{~g}$

[19] S. Huh, J. W. Wiench, J.-C. Yoo, M. Pruski and V. S.-Y. Lin, "Organic Functionalization and Morphology Control of Mesoporous Silicas via a Co-Condensation Synthesis Method," Chemistry of Materials, Vol. 15, No. 22, 2003, pp. 4247-4256. doi:10.1021/cm0210041 
[20] A. Gervasini, C. Messi, P. Carniti, A. Ponti, N. Ravasio and F. Zaccheria, "Insight into the Properties of Fe Oxide Present in High Concentrations on Mesoporous Silica," Journal of Catalysis, Vol. 262, No. 2, 2009, pp. 224-234. doi:10.1016/j.jcat.2008.12.016

[21] P. C. Bakala, E. Briot, J.-Y. Piquemal, J.-M. Brégeault and P. Beaunier, "Comparison of the Conventional Impregnation Method Using Ammonium Heptamolybdate with a Simple Route to Silica-Supported Molybdenum(VI) Materials," Catalysis Communications, Vol. 8, No. 10, 2007, pp. 1447-1451. doi:10.1016/j.catcom.2006.12.015

[22] A. Gervasini, "Characterization of the Textural Properties of Metal Loaded Zsm-5 Zeolites," Applied Catalysis A: General, Vol. 180, No. 1-2, 1999, pp. 71-82. doi:10.1016/S0926-860X(98)00333-0

[23] E. P. Barrett, L. G. Joyner and P. Halenda, "The Determination of Pore Volume and Area Distributions in Porous Substances. I. Computations from Nitrogen Isotherms," Journal of the American Chemical Society, Vol. 73, No. 1, 1951, pp. 373-380. doi:10.1021/ja01145a126

[24] P. Malet and A. Caballero, "The Selection of Experimental Conditions in Temperature-Programmed Reduction Experiments," Journal of the Chemical Society, Faraday Transactions 1, Vol. 84, No.7, 1988, pp. 2369-2375. doi:10.1039/f19888402369

[25] D. A. M. Monti and A. Baiker, "Temperature-Programmed Reduction. Parametric Sensitivity and Estimation of Kinetic Parameters," Journal of Catalysis, Vol. 83, No. 2, 1983, pp. 323-335. doi:10.1016/0021-9517(83)90058-1

[26] P. Carniti, A. Gervasini and S. Bennici, "Experimental and Modelization Approach in the Study of Acid-Site Energy Distribution by Base Desorption. Part I: Modified Silica Surfaces," Journal of Physical Chemistry B, Vol. 109, No. 4, 2005, pp. 1528-1536. doi:10.1021/jp047889g

[27] A. Gervasini, C. Messi, D. Flahaut and C. Guimon, "Acid Properties of Iron Oxide Catalysts Dispersed on SilicaZirconia Supports with Different Zr Content," Applied Catalysis A: General, Vol. 367, No. 1-2, 2009, pp. 113121. doi:10.1016/j.apcata.2009.07.044

[28] A. W. Miller, W. Atkinson, M. Barber and P. Swift, "The High Energy Photoelectron Spectra of Molybdenum in Some $\mathrm{Mo} / \mathrm{Al}_{2} \mathrm{O}_{3}$ Systems," Journal of Catalysis, Vol. 22, No. 1, 1971, pp. 140-142. doi:10.1016/0021-9517(71)90274-0

[29] G. Muralidhar, B. E. Concha, G. I. Bartholomew and C. H. Bartholomew, "Characterization of Reduced and Sulfided, Supported Molybdenum Catalysts by $\mathrm{O}_{2}$ Chemisorption, X-Ray Diffraction, and ESCA," Journal of Catalysis, Vol. 89, No. 2, 1984, pp. 274-284. doi:10.1016/0021-9517(84)90305-1

[30] N. K. Nag, "A Comparative Study on the Dispersion and Carrier-Catalyst Interaction of Molybdenum Oxides Supported on Various Oxides by Electron Spectroscopy for Chemical Analysis," The Journal of Physical Chemistry, Vol. 91, No. 9, 1987, pp. 2324-2327. doi:10.1021/j100293a023

[31] C. V. Cáceres, J. L. G. Fierro, J. Lázaro, A. López Agudo and J. Soria, "Effect of Support on the Surface Characteristics of Supported Molybdena Catalysts," Journal of
Catalysis, Vol. 122, No. 1, 1990, pp. 113-125. doi:10.1016/0021-9517(90)90265-L

[32] Y. V. Plyuto, I. V. Babich, I. V. Plyuto, A. D. Van Langeveld and J. A. Moulijn, "XPS Studies of $\mathrm{MoO}_{3} / \mathrm{Al}_{2} \mathrm{O}_{3}$ and $\mathrm{MoO}_{3} / \mathrm{SiO}_{2}$ Systems," Applied Surface Science, Vol. 119, No. 1-2, 1997, pp. 11-18. doi:10.1016/S0169-4332(97)00185-2

[33] M. A. Bañares, J. L.G Fierro and J. B. Moffat, "The Partial Oxidation of Methane on $\mathrm{MoO}_{3} / \mathrm{SiO}_{2}$ Catalyst: Influence on the Molybdenum Content and Type of Oxidant," Journal of Catalysis, Vol. 142, No. 2, 1993, pp. 406-417. doi:10.1006/jcat.1993.1218

[34] T.-J. Yang and J. H. Lunsford, "Partial Oxidation of Methanol to Formaldehyde over Molybdenum Oxide on Silica," Journal of Catalysis, Vol. 103, No. 1, 1987, pp. 55-64. doi:10.1016/0021-9517(87)90092-3

[35] F. Solymosi, A. Erdöhelyi and A. Szöke, "Dehydrogenation of Methane on Supported Molybdenum Oxides. Formation of Benzene from Methane," Catalysis Letters, Vol. 32, No. 1-2, 1995, pp. 43-53. doi:10.1007/BF00806100

[36] F. E. Massoth, G. Muralidhar and J. Shabtai, "Catalytic Functionalities of Supported Sulfides: II. Effect of Support on Mo Dispersion," Journal of Catalysis, Vol. 85, No. 1, 1984, pp. 53-62. doi:10.1016/0021-9517(84)90109-X

[37] R. D. Roark, S. D. Kohler and J. G. Ekerdt, "Role of Silanol Groups in Dispersing Mo(VI) on Silica," Catalysis Letters, Vol. 16, No. 1-2, 1992, pp. 71-76. doi:10.1007/BF00764356

[38] P. Maksimowski and W. Skupinski, "Catalytic of Supported Tungsten and Molybdenum Complexes in Olefin Methatesis," Journal of Molecular Catalysis, Vol. 65, No. 1-2, 1991, pp. 187-192. doi:10.1016/0304-5102(91)85095-J

[39] S. O. Grim and L. J. Matienzo, "X-Ray Photoelectron Spectroscopy of Inorganic and Organometallic Compounds of Molybdenum," Inorganic Chemistry, Vol. 14, No. 5, 1975, pp. 1014-1018. doi:10.1021/ic50147a013

[40] H. Al-Kandari, F. Al-Kandari and A. Katrib, "Surface Electronic Structure-Catalytic Activity of Different Mo Oxidation States for Olefins and Saturated Hydrocarbon Molecules," Catalysis Letters, Vol. 139, No. 3-4, 2010, pp. 134-140. doi:10.1007/s10562-010-0414-0

[41] M. Mieterle, G. Weinberg and G. Mestl, "Raman Spectroscopy of Molybdenum Oxides Part I. Structural Characterization of Oxygen Defects in $\mathrm{MoO}_{3-\mathrm{x}}$ by DR UV/ VIS, Raman Spectroscopy and X-Ray Diffraction," Physical Chemistry Chemical Physics, Vol. 4, No. 5, 2002, pp. 812-821.

[42] M. A. Larrubia and G. Busca, "An Ultraviolet-VisibleNear Infrared Study of the Electronic Structure of Oxide Supported Vanadia-Tungsta and Vanadia-Molybdena," Materials Chemistry and Physics, Vol. 72, No. 3, 2001, pp. 337-346. doi:10.1016/S0254-0584(01)00329-7

[43] C. C. Williams, J. G. Ekerdt, J.-M. Jehng, F. D. Hardcastle, A. M. Turek and I. E. Wachs, "A Raman and Ultraviolet Diffuse Reflectance Spectroscopic Investigation of Silica-Supported Molybdenum Oxide," The Journal of 
Physical Chemistry, Vol. 95, No. 22, 1991, pp. 87818791. doi:10.1021/j100175a068

[44] J. Fournier, C. Louis, M. Che, P. Chaquin and D. Masure, "Polyoxometallates as Models for Oxide Catalysts: Part I. An UV-Visible Reflectance Study of Polyoxomolybdates: Influence of Polyhedra Arrangement on the Electronic Transitions and Comparison with Supported Molybdenum Catalysts," Journal of Catalysis, Vol. 119, No. 2, 1989, pp. 400-414. doi:10.1016/0021-9517(89)90170-X

[45] M. A. Bañares and J. L. G. Fierro, "Selective Oxidation of Methane to Formaldehyde on Supported Molybdate Catalysts," Catalysis Letters, Vol. 17, No. 3-4, 1993, pp. 205-211. doi:10.1007/BF00766143

[46] P. Gajardo, P. Grange and B. Delmon, "Physicochemical Characterization of the Interaction between Cobalt Molybdenum Oxide and Silicon Dioxide. 1. Influence of the Cobalt-Molybdenum Ratio," The Journal of Physical Chemistry, Vol. 83, No. 13, 1979, pp. 1771-1779. doi:10.1021/j100476a018

[47] K. Marcinkowska, L. Rodrigo, S. Kaliaguine and P. C. Roberge, "Characterization of Supported $\mathrm{Mo}(\mathrm{VI}) / \mathrm{SiO}_{2}$ : The Effects of Water Leaching and Support Dehydroxylation," Journal of Catalysis, Vol. 97, No. 1, 1986, pp. 75-84. doi:10.1016/0021-9517(86)90039-4

[48] J. P. Thielemann, T. Ressler, A. Walter, G. TzolovaMüller and C. Hess, "Structure of Molybdenum Oxide Supported on Silica SBA-15 Studied by Raman, UV-Vis and X-Ray Absorption Spectroscopy," Applied Catalysis A: Genera., Vol. 399, No. 1-2, 2011, pp. 28-34. doi:10.1016/j.apcata.2011.03.032

[49] F. Arena and A. Parmaliana, "Silica-Supported Molybdena Catalysts. Surface Structures, Reduction Pattern, and Oxygen Chemisorption," The Journal of Physical Chemistry, Vol. 100, No. 51, 1996, pp. 19994-20005. doi:10.1021/ip9618587

[50] H. M. Ismail, M. I. Zaki, G. C. Bond and R. Shukri, "Temperature-Programmed Reduction of $\mathrm{MoO}_{\mathrm{x}} / \mathrm{SiO}_{\mathrm{x}}$ and $\mathrm{MoO}_{\mathrm{x}} / \mathrm{Al}_{2} \mathrm{O}_{3}$ Catalysts. Surface Structural Consequences of Impregnation Acidity," Applied Catalysis A General, Vol. 72, No. 1, 1991, pp. L1-L12.

[51] R. L. Cordero, F. J. G. Lambias and A. L. Agudo, “Temperature Programmed Reduction and Zeta Potential Studies of Structure of $\mathrm{MoO}_{3} / \mathrm{Al}_{2} \mathrm{O}_{3}$ and $\mathrm{MoO}_{3} / \mathrm{SiO}_{2}$ Catalysts. Effect of the Impregnation $\mathrm{pH}$ and Molybdenum Loading," Applied Catalysis A: General, Vol. 74, No. 1, 1991, pp. 125-136. doi:10.1016/0166-9834(91)90013-X

[52] M. De Boer, A. J. van Dillen, D. C. Koninsberger, J. W.
Geus, M. A. Vuurman and I. E. Wachs, "Remarkable Spreading Behavior of Molybdena on Silica Catalysts. An in Situ EXAFS-Raman Study," Catalysis Letters, Vol. 11, No. 2, 1991, pp. 227-239. doi:10.1007/BF00764089

[53] H. Tian, C. A. Roberts and I. E. Wachs, "Molecular Structural Determination of Molybdena in Different Environments: Aqueous Solutions, Bulk Mixed Oxides, and Supported $\mathrm{MoO}_{3}$ Catalysts," The Journal of Physical Chemistry C, Vol. 114, No. 33, 2010, p. 14110. doi:10.1021/jp103269w

[54] M. A. Baňares, H. Hu and I. E. Wachs, "Molybdena on Silica Catalysts: Role of Preparation Methods on the Structure-Selectivity Properties for the Oxidation of Methano," Journal of Catalysis, Vol. 150, No. 2, 1994, pp. 407-420. doi:10.1006/jcat.1994.1359

[55] S. R. Seyedmonir and R. F. Howe, "Redox Chemistry of Molybdena-Silica Catalysts: 1. Characterization and Thermal Reduction," Journal of Catalysis, Vol. 110, No. 2, 1988, pp. 216-228. doi:10.1016/0021-9517(88)90314-4

[56] J. C. Vedrine, "The Role of Redox, Acid-Base and Collective Properties and of Cristalline State of Heterogeneous Catalysts in the Selective Oxidation of Hydrocarbons," Topics in Catalysis, Vol. 21, No. 1-3, 2002, pp. 97-106. doi:10.1023/A:1020560200125

[57] T. Kataoka and J. A. Dumesic, "Acidity of Unsupported and Silica-Supported Vanadia, Molybdena, and Titania as Studied by Pyridine Adsorption," Journal of Catalysis, Vol. 112, No. 1, 1988, pp. 66-79. doi:10.1016/0021-9517(88)90121-2

[58] S. Rajagopal, J. A. Marzari and R. Miranda, "Silica-Alumina-Supported Mo Oxide Catalysts: Genesis and Demise of Brønsted-Lewis Acidity," Journal of Catalysis, Vol. 151, No. 1, 1995, pp. 192-203. doi:10.1006/jcat.1995.1021

[59] C. F. Mao and M. A. Vannice, "Formaldehyde Oxidation over Ag Catalysts," Journal of Catalysis, Vol. 154, No. 2, 1995, pp. 230-244. doi:10.1006/jcat.1995.1165

[60] W.-H. Cheng, "Methanol and Formaldehyde Oxidation Study over Molybdenum Oxide," Journal of Catalysis, Vol. 158, No. 2, 1996, pp. 477-485. doi:10.1006/jcat.1996.0047

[61] R. L. McCormick, M. B. Al-Sahali and G. O. Alptekin, "Partial Oxidation of Methane, Methanol, Formaldehyde, and Carbon Monoxide over Silica: Global Reaction Kinetics," Applied Catalysis A: General, Vol. 226, No. 1-2, 2002, pp. 129-138. doi:10.1016/S0926-860X(01)00894-8 